\title{
Experimental and numerical investigations on nitrogen species transport in unsaturated soil during various irrigation patterns
}

\author{
M BERLIN $^{1}$, INDUMATHI M NAMBI ${ }^{1}$ and G SURESH KUMAR ${ }^{2, *}$ \\ ${ }^{1}$ EWRE Division, Department of Civil Engineering, Indian Institute of Technology \\ Madras, Chennai 600 036, India \\ ${ }^{2}$ Department of Ocean Engineering, Indian Institute of Technology Madras, \\ Chennai 600 036, India \\ e-mail: berlin1982@gmail.com; indunambi@iitm.ac.in; gskumar@iitm.ac.in
}

MS received 17 November 2014; revised 27 May 2015; accepted 28 May 2015

\begin{abstract}
The transport of nitrogen coming from wastewater applied agricultural field is a major problem in assessing the vulnerability of groundwater contamination. In this study, laboratory column experiments are conducted in order to simulate the paddy, groundnut and wheat irrigation with wastewater. The experiments are carried out with high clay content $(\approx 35 \%)$ soil from Kancheepuram, Tamilnadu and low clay $(\approx 9 \%)$ soil from Ludhiana, Punjab, India. Furthermore, a numerical model and HYDRUS-1D model are developed to simulate the experimental results. The experimental results show that there is no effluent collected at the bottom of the column during groundnut irrigation in Kancheepuram soil and effluent collected except during first irrigation in the case of wheat irrigation in Ludhiana soil. The experimental and numerical results illustrate that when $50 \mathrm{mg} / \mathrm{l}$ of ammonium and $20 \mathrm{mg} / \mathrm{l}$ of nitrate nitrogen applied during paddy irrigation, the peak nitrate nitrogen concentration of $50 \mathrm{mg} / \mathrm{l}$ is arrived after 10 days in Kancheepuram soil due to low permeability and relatively less background soil nitrogen. But in the case of Ludhiana soil with 94 $\mathrm{mg} / \mathrm{l}$ of total nitrogen applied during paddy irrigation, the peak nitrate nitrogen concentration of $1,620 \mathrm{mg} / \mathrm{l}$ is observed at first day due to high permeability and high soil background nitrogen concentration. Additionally, the model results show that the application of high nitrogen content wastewater for irrigation in Ludhiana soil will affect the groundwater quality even when the groundwater table is deep as compared with Kancheepuram soil.
\end{abstract}

Keywords. Nitrogen species; numerical modeling; HYDRUS-1D; irrigation; unsaturated zone.

${ }^{*}$ For correspondence 


\section{Introduction}

The scarcity of water resources is one of the most challenging problems in many developed and developing countries. India has nearly $53.4 \%$ of land covers under arid and semi-arid regions (NATCOM 2004) due to low volumes of rainfall. Furthermore, India is an agricultural country and about $70 \%$ of population depends on agriculture. Agricultural sector is demanding more amount of water as compared with other sectors such as domestic and industry. Hence, wastewater reuse has become an important technique for conserving the existing water bodies and reduction of fertilizer application due to the availability of nutrients in the wastewater. However, the wastewater application for agriculture practice can contaminate the groundwater due to the leaching of various pollutants such as nitrate, calcium, sulphate, sodium, and heavy metals (Asano \& Levine 1995; Lubello et al 2004; Sheng 2005; Pedrero et al 2010).

Treated or partially treated wastewater can be a good alternative water source for supplementary irrigation in areas which suffer from water shortage since the prescribed standards for irrigation water is less stringent compared to drinking water standards (Kang et al 2007; Jang et al 2010). There are many reports available on the usage of treated wastewater for irrigation purposes in several countries (Cooper 1991; Asano \& Levine 1996; Al-Lahham et al 2003; Kiziloglu et al 2007; Brunetti et al 2007; Palese et al 2009). Since paddy cultivation requires large quantities of water and nutrients, therefore treated wastewater becomes one of the good sources for paddy irrigation. There have been studies which have examined the issue of groundwater quality during application of the wastewater for paddy irrigation (Han et al 1999; Cho \& Choi 2001; Cho 2003; Yoon et al 2006). Furthermore, it is challenging to study the practical wastewater use containing high nutrient concentration during paddy irrigation. Jang et al (2012) have investigated the water and nutrient balances in paddy fields irrigated by groundwater, wastewater, and reclaimed wastewater. Some recent studies addressed the (i) impact of reclaimed wastewater irrigation on nutrient loads from the paddy field (Kim et al 2007), (ii) effect of the application of reclaimed municipal wastewater on rice cultivation (Papadopoulos et al 2009) (iii) environmental impacts of reclaimed wastewater irrigation on water quality and soil in paddy fields (Jang et al 2013). Similarly detailed study on cultivation of groundnut (Ramana et al 2002; Bradford et al 2003) and wheat (Rinaldi et al 2003; Pathak et al 1999; Mojid et al 2012) has shown that the wastewater is a good source and option for irrigation.

Several studies have reported the nitrogen species concentration in a paddy cultures soil by experimental and field monitoring. Some evidence show that the nitrate concentration in groundwater was exceeding the permissible limit due to leaching of fertilizer or wastewater applied paddy and wheat field (Babiker et al 2004; Zhu et al 2000; Riley et al 2001). The influence of soil texture, bulk density and organic matter content on the process of nitrate vertical transport in paddy soils of the Tai Lake region was studied in the soil columns by Chen et al (2007). Their investigations suggest that the transport on nitrate was affected by clay content. Conversely low bulk density and high organic matter content were each associated with faster nitrate transport. Zhao et al (2010) have determined nitrogen recovered by rice and wheat, nitrogen remained in soil, and the losses of reactive nitrogen (i.e., $\mathrm{NH}_{3}, \mathrm{~N}_{2} \mathrm{O}, \mathrm{NO}_{3}$, organic $\mathrm{N}$ and $\mathrm{NH}_{4}$ ) to the environment. Nitrogen leaching from paddy field under different fertilization rates was studied by Iqbal (2010). The results showed that ammonium nitrogen was the main form of nitrogen with a high environmental risk during the paddy growth. Experimental evidence shows the nitrate was found to be leaching from wheat field during nitrogen fertilization with the influences of rainfall, nitrogen fertilization rate and temperature (Qiang et al 2011). Laboratory analysis was performed using lysimeters by Haijun et al (2013) to determine the ammonia and nitrous oxide emissions and nitrogen leaching losses in a rice-wheat cropping system irrigated with nitrogen 
rich wastewater from a livestock pond. Further field examination performed by Zhou et al (2013) on nitrate leaching in nitrogen fertilized wheat-maize rotation using free drainage lysimeters. The dissolved organic carbon is also identified as a one of the important parameters on nitrate variation (Lee et al 2006) in wastewater or urea applied paddy field (Berlin et al 2014a). The effect of dissolved oxygen variation on nitrogen species is another important factor which was studied by many researches (MacQuarrie et al 2001; Kim et al 2004; Berlin et al 2014b).

Transport modeling is a predictive and descriptive tool to provide highly accurate information about the location and concentration of contaminants in the subsurface system. Many modeling studies on nitrate transport in saturated and unsaturated porous media considering numerous physicochemical processes such as advection, dispersion, sorption, mineralization, nitrification, denitrification, volatilization, atmospheric deposition and plant nutrient uptake have been well documented (Wu et al 1997; MacQuarrie et al 2001; Roose \& Fowler 2004; Mohammad 2007). Lee et al (2006) addressed the fate and transport of nitrogen species in the saturated zone using mathematical modeling along with experimental evidences. Liang et al (2007) have attempted the modeling of nitrogen species concentration in the paddy soil under saturated/unsaturated conditions. Berlin et al (2013) have numerically analyzed the nitrogen species transport in unsaturated zone under non-isothermal conditions. Recent modeling result suggests that biological clogging is also play a predominant role on nitrogen species transport and transformation in sub-surface system (Berlin et al 2014c). These mathematical models can be used to predict the concentration of contaminants at various depths and time. On the other hand, many of the models lack the capability to account for naturally existing soil spatial heterogeneity and complex bio-chemical process.

The detailed literature study shows that the nitrogen dynamics in the sub-surface can vary depends on various irrigation patters based on the crop requirement, fertilizer application, soil type, soil hydraulic parameters and different environmental factors. Paddy, groundnut and wheat are some of the major crops cultivated all over India. Water requirement and irrigation pattern vary with each crop. Therefore, it is important to estimate the nitrogen leaching during wastewater application for various crop irrigations in order to preserve the ground water quality. However, relatively less attention has been provided to how the irrigation pattern and the soil hydraulic characteristics are controlling the transport and transformation phenomena of nitrogen species in the subsurface especially during treated or untreated industrial wastewater application. This study addresses the effective usage of treated and untreated textile industry wastewater for irrigation purpose. The objective of this study is to understand the nitrogen dynamics during textile wastewater application in (i) varying hydraulic properties of soil and (ii) varying irrigation pattern with respect to crop water requirement for different crops (paddy, groundnut and wheat) performed using soil column studies in laboratory scale. A numerical model is developed to simulate the soil column experiments for the prediction of nitrogen species concentration at the outlet of soil column. HYDRUS-1D software is also used for simulating the nitrogen dynamics to cross-validate the developed numerical model. Furthermore, sensitivity study is performed on partition coefficient of ammonium nitrogen, nitrification rate, denitrification rate and dissolved organic carbon to understand the nitrogen dynamics in subsurface soil system.

\section{Study area}

In order to simulate the nitrogen species dynamics in hydraulically varying soil types, two sites were selected for this study. In this regard a site in Kancheepuram, Tamilnadu was selected for soil containing relatively high clay compared to other site located in Ludhiana, Punjab, for soil 
containing high sand content. The details about these sites are explained in this section. The study area map for both sites is shown in figure 1.

\subsection{Location}

Kancheepuram, Tamilnadu is a historical town in the south India, which is geographically located at $12^{\circ} 50^{\prime} \mathrm{N}$ latitude and $79^{\circ} 42^{\prime} \mathrm{E}$ longitude at a distance of $72 \mathrm{~km}$ south-west of Chennai, Tamilnadu. It is located on the banks of the Vegavathy river, a tributary of Palar river at an altitude of $83.26 \mathrm{~m}$ above MSL. This town has a natural gradient towards Manjal Neer channel and towards Vegavathy river in the south.

Ludhiana is located at $30.9^{\circ} \mathrm{N}$ and $75.85^{\circ} \mathrm{E}$ in the Indian state of Punjab. It is located $100 \mathrm{~km}$ west from Chandigarh, Punjab. Sutlej and Budha nallah are the two rivers, which are flowing through this district. The mean elevation of Ludhiana city is $244 \mathrm{~m}$ from MSL.

\subsection{Rainfall and climate}

Generally, Kancheepuram district experiences hot and humid climatic conditions. Kancheepuram district receives the rain during the both southeast and northeast monsoons, mainly due to the effect of depressions in Bay of Bengal during northeast monsoon season. The normal annual rainfall varies from $1,105 \mathrm{~mm}$ to $1,214 \mathrm{~mm}$. The relative humidity varies between $58 \%$ and $84 \%$ while the temperature varies between $20^{\circ} \mathrm{C}$ and $43^{\circ} \mathrm{C}$.

Ludhiana has very hot summer and very cold winters with three different seasons such as summer, monsoon and winter. Monsoon visits this city during July and extends up to September.

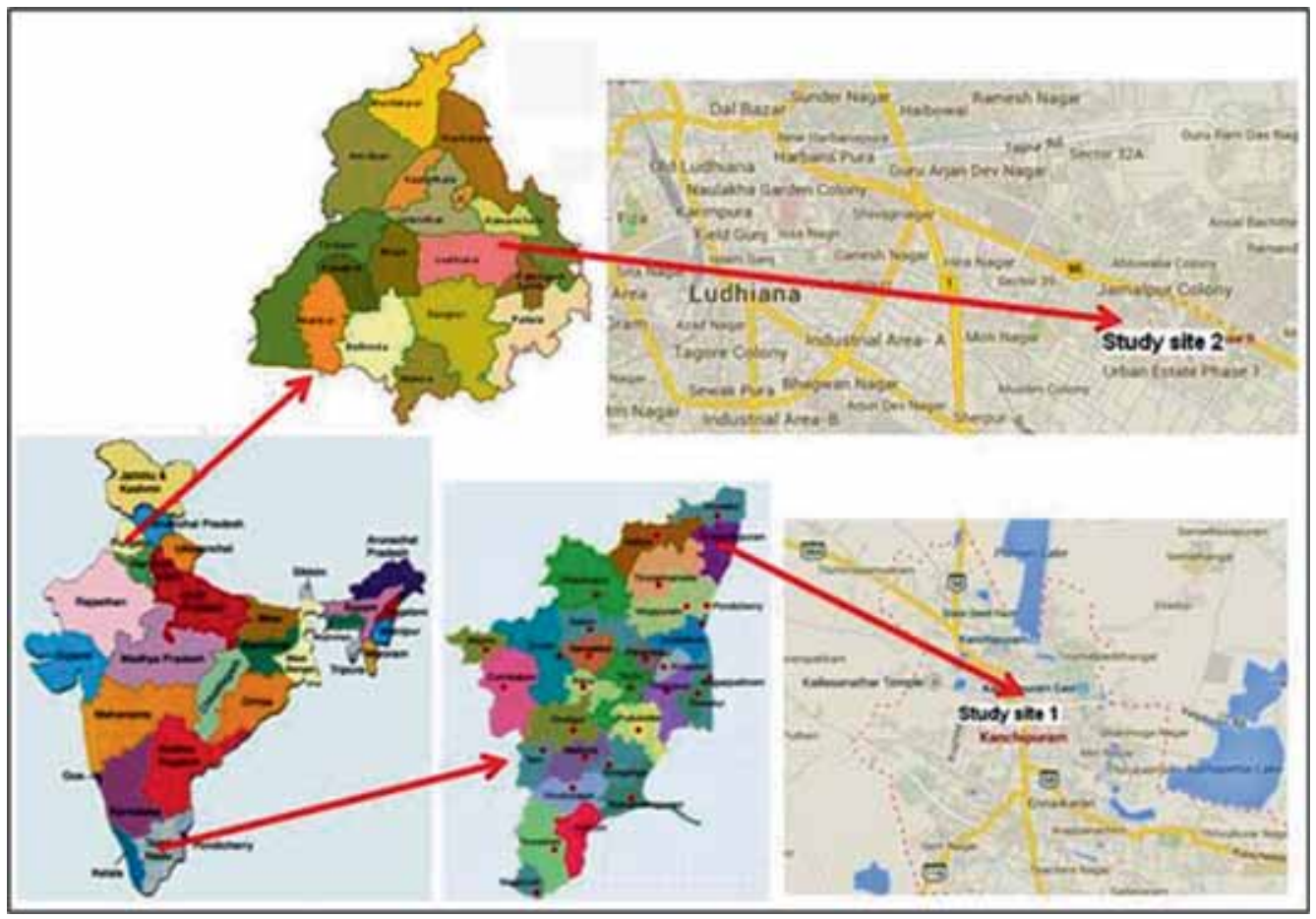

Figure 1. Study site of Kancheepuram, Tamilnadu (Study site 1) and Ludhiana, Punjab (Study site 2), India. 
The normal annual rainfall of the Ludhiana district is $680 \mathrm{~mm}$ nearly $78 \%$ of annual rainfall is contributed between June and September by southwest monsoon. The temperature can vary between $-5.2^{\circ} \mathrm{C}$ and $44^{\circ} \mathrm{C}$.

\subsection{Industrialization}

In Kancheepuram, nearly 50 rice mill units are located around Oli Mohammed Pettai, Thamaraikulam, Vellaikulam and Satan Kulam. Approximately 60 small scale dyeing units are located in the residential areas, mainly along Vegavathy river in the southern part of Kancheepuram town. Silk and cotton yarn twisting units are also situated in and around the Kancheepuram town. Large amount of wastewater can be generated from these industries particularly from dyeing units and textile industries during the processes such as spinning, bleaching and coloring. The effluents from these industries consists of high concentrations of total dissolved solids, biochemical oxygen demand, sodium, chloride, ammonia, nitrates, sulphates, hardness, heavy metals and carcinogenic dye ingredients (Tchobanoglous \& Burton 1995). At present, wastewater generated from these industries is simply discharged into the soil without proper treatment. In Kancheepuram, nearly 50 rice mill units are located around Oli Mohammed Pettai, Thamaraikulam, Vellaikulam and Satan Kulam. Approximately 60 small scale dyeing units are located in the residential areas, mainly along Vegavathy river in the southern part of Kancheepuram town. Silk and cotton yarn twisting units are also situated in and around the Kancheepuram town. Large amount of wastewater can be generated from these industries particularly from dyeing units during the processes such as spinning, bleaching and coloring. The effluents from these industries consist of high concentrations of total dissolved solids, biochemical oxygen demand, sodium, chloride, ammonia, nitrates, sulphates, hardness, heavy metals and carcinogenic dye ingredients (Tchobanoglous \& Burton 1995). At present, wastewater generated from these industries is simply discharged into the soil without proper treatment.

Ludhiana has done remarkably well in the field of agriculture for long time and due to rapid industrialization through small, medium and large scale industries it is universally famous as the Manchester of India and industrial capital of small scale industries in the country. As per MSME (2014) report, nearly 6,750 textile units, 2,460 units of leather products, 3,547 units of fabricated metal products and lot of other micro and small scale industries are situated in Ludhiana district during 2010-2011. Malwa Industries limited, Vardhman Textile limited and M/S Mills are some of the large scale industries in the textile sector. Even though the large scale textile industries are treating the effluents to some extent, but the small and medium scale industries are discharging their effluents in the soil without proper treatment which may eventually contaminate the groundwater.

\subsection{Groundwater resources}

Groundwater resource is the one of the prime source of drinking water in Kancheepuram, Tamilnadu. Generally, the water table is available at a depth of 2.89-4.09 m during summer season and 1.05-3.40 m from ground level during winter season in this area (Water Year 2007). Study by Balakrishnan et al (2008) revealed that the groundwater source in Kancheepuram is not suitable for drinking purpose mainly due to the disposal of partially treated wastewater from these industries on the land fields. Their results show that the concentration of total dissolved solids (1,138-2,574 mg/L), chloride (216-847 mg/L), total hardness (225-760 mg/L), sulphate (64$536 \mathrm{mg} / \mathrm{L}$ ), nitrate (up to $58 \mathrm{mg} / \mathrm{L}$ ), iron (up to $2.3 \mathrm{mg} / \mathrm{L}$ ) and lead (up to $0.281 \mathrm{mg} / \mathrm{L}$ ) were found to be higher and exceeded the permissible limits of WHO standards. 
Generally, the depth to groundwater in Ludhiana varies between 9 and $26 \mathrm{~m}$ from the ground level. This groundwater table depth can vary during the pre-monsoon period from 9.24 to 25.48 $\mathrm{m}$ while during post-monsoon seasons it ranges between 5.09 and $33.62 \mathrm{~m}$ (CGWB 2007). In general the groundwater of the Ludhiana district is fresh except in and around Ludhiana city where the ground water is polluted due to industrial effluents (CGWB 2007).

\section{Materials and methods}

This section describes the detailed methodology along with the analysis of soil and wastewater samples collected from Kancheepuram, Tamilnadu and Ludhiana, Punjab to estimate the physical and chemical properties of soil and wastewater. Column experiments were also performed in the laboratory to understand the nitrogen dynamics in these soils with synthetic wastewater replicating the actual wastewater collected from textile industries. Modeling studies have also been carried out to reproduce the nitrogen species transport and transformation in the soil column for future predictions.

\subsection{Soil and wastewater analysis}

Soil samples were collected from the root zone below $15 \mathrm{~cm}$ from ground level in Kancheepuram and Ludhiana for physical and chemical analysis. Various experiments were conducted to find the soil physical parameters such as particle size distribution, specific gravity, dry density, bulk density and permeability. Similarly, soil chemical analysis such as $\mathrm{pH}$, organic carbon, inorganic carbon, total carbon content, background ammonium and nitrate nitrogen concentrations was also analyzed. The treated wastewater samples were also collected from textile industries from both study sites and the chemical parameters were also analyzed.

3.1a Wastewater sample analysis: Since there was no proper treatment of wastewater generated from the textile industries in Kancheepuram, Tamilnadu, the wastewater generated from these industries are discharged into the public sewer line. These effluents are mixed with domestic wastewater and finally reach the waste stabilization pond. Thus, the wastewater samples were collected at various outlets of silk dyeing units such as direct dye bath, degumming unit effluent, silk washing unit, outlet of dyeing unit and the waste stabilization pond. The other set of samples were collected from Vardhman textile industries, Ludhiana, Punjab at different points in the treatment unit such as influent sample in the treatment plant, secondary sedimentary tank, biological treatment tank and final effluent from the treatment plant.

\subsection{Pressure plate apparatus}

Pressure plates are normally used to establish the moisture characteristics of soil. The soil paste was prepared by saturating with water and was placed in the plastic retaining rings on the porous plate. Once the soil samples were kept in the pressure chamber, the clamping bolts were properly sealed. By adjusting the pressure valve, required pressure inside the pressure chamber using compressor was built up. Samples can be removed when the soil sample approaches the equilibrium (approximately 18-20 h). This procedure can be repeated for different pressures to arrive a set of water content for the corresponding pressure head. The water content can be calculated for each pressure applied as given in the following equation:

$$
\text { Water content }=\left(W_{2}-W_{3}\right) /\left(W_{3}-W_{1}\right)
$$


where $W_{1}$ is the weight of the empty container $(\mathrm{g}) ; W_{2}$ is the wet weight of soil with container after immediately taking out the soil sample from the pressure plate apparatus and $W_{3}$ is the dry weight of soil with container after $24 \mathrm{~h}$ of oven dried soil sample.

\subsection{Column experiments}

Column experiments were conducted to study the distribution of nitrogen species concentration during different irrigation scenarios performed with treated or partially treated textile wastewater for Kancheepuram and Ludhiana soil samples. Since paddy and groundnut are the main crops in Kancheepuram, the corresponding irrigation patterns were simulated in the lab to establish the concentration profile at the bottom of the soil column. Similarly, paddy and wheat are the predominant crops in Ludhiana, and the corresponding irrigation patterns were simulated for these soil samples. In order to mimic the field conditions, the soil was filled in the column with the same density as measured in the field. The designed soil columns have $70 \mathrm{~cm}$ depth and $6 \mathrm{~cm}$ in diameter as shown in figure 2. The bottom of the soil column was filled with coarse sand up to $5 \mathrm{~cm}$ to prevent the clogging process at the bottom of the column due to fine soil particles. The field soil was effectively filled up to $60 \mathrm{~cm}$ depth from the bottom of the column. To simulate the nitrogen species concentration, three columns were run in parallel; in which two columns were simulated for paddy and one for groundnut irrigation scenario with same concentration of synthetically prepared wastewater in Kancheepuram soil. But in the case of Ludhiana soil

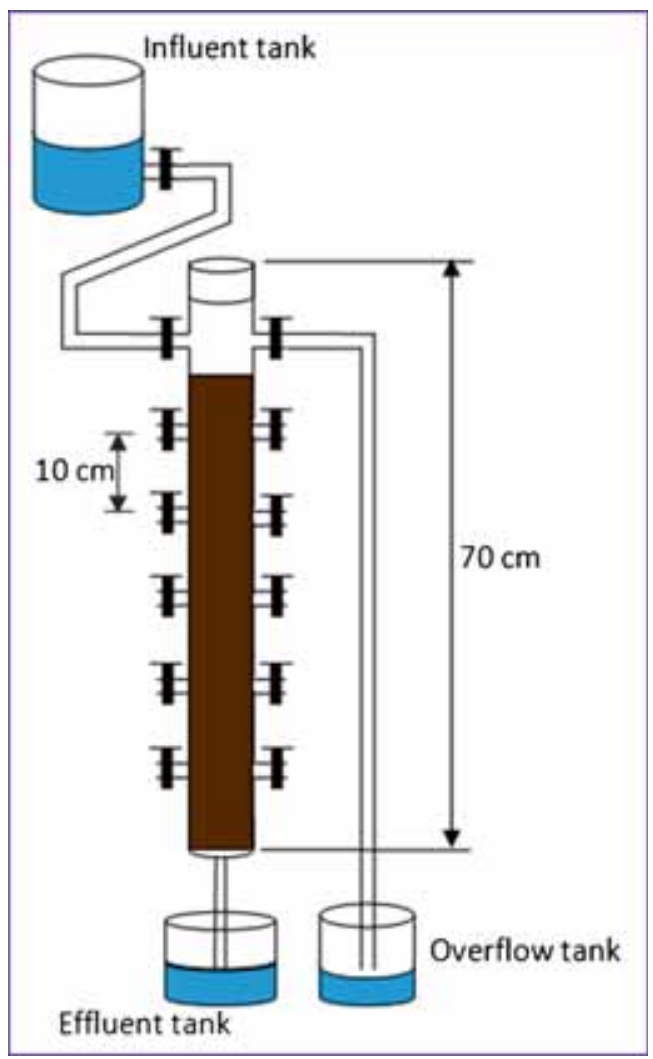

Figure 2. Column experimental setup. 
one soil column was dedicated for treated wastewater scenario and other two soil columns were devoted for untreated wastewater scenario in which one was simulated for paddy and one for wheat irrigation pattern.

3.3a Synthetic wastewater preparation and column experimental procedure: Synthetic wastewater was prepared with the chemical composition of $50 \mathrm{mg} / \mathrm{l}$ of ammonium nitrogen, $20 \mathrm{mg} / \mathrm{l}$ of nitrate nitrogen and 1,500 mg/l of COD (Chemical Oxygen Demand) in order to resemble the Kancheepuram textile wastewater to conduct the soil column experiments. Similarly, the chemical composition of $30 \mathrm{mg} / \mathrm{l}$ of ammonium nitrogen, $64 \mathrm{mg} / \mathrm{l}$ of nitrate nitrogen and 2,800 $\mathrm{mg} / \mathrm{l}$ of COD for untreated wastewater scenario while $7 \mathrm{mg} / \mathrm{l}$ of ammonium nitrogen, $7 \mathrm{mg} / \mathrm{l}$ of nitrate nitrogen and 1,700 $\mathrm{mg} / \mathrm{l}$ of COD for treated wastewater scenario resembling the Ludhian a textile wastewater. Since this study mainly focused on nitrogen species transport in unsaturated soil, the other contaminants in the textile industrial wastewater were not considered during synthetic wastewater preparation. The wastewater was applied continually for 100 days with the standing depth of $3 \mathrm{~cm}$ (Chinh et al 2008) to simulate the paddy irrigation while for groundnut irrigation simulation the total water requirement $(510 \mathrm{~mm})$ was split into seven intervals and for wheat irrigation simulation the total water requirement $(650 \mathrm{~mm})$ was split into five divisions as per the guidelines prescribed by the TNAU (Tamil Nadu Agricultural University). The synthetic wastewater was applied at the top of the column and the effluent was collected from the bottom at regular intervals. Care was taken to prevent evaporation losses by covering the collection vessel with polythene sheets. The collected effluent was analyzed by water quality probes to check the concentration of ammonium and nitrate nitrogen species.

\subsection{Model formulation}

The mathematical model for predicting water flow and the transport of nitrogen species in unsaturated sub-surface system is described in this section to simulate the nitrogen species in the various soil conditions and irrigation scenarios.

Vertical movement of water in soil under one-dimensional unsaturated condition can be described by Richard's model as expressed in Eqs. (2)-(5) (Antonopoulos 2006):

$$
C(h) \frac{\partial h}{\partial t}=\frac{\partial}{\partial z} K\left(\frac{\partial h}{\partial z}\right)-\frac{\partial K}{\partial z}-S(z, t)
$$

where $C(h)=\frac{\partial \theta}{\partial h}$ is specific moisture capacity $(1 / \mathrm{L}) ; h$ is the pressure head $(\mathrm{L}) ; K$ is the unsaturated hydraulic conductivity $(\mathrm{L} / \mathrm{T}) ; t$ is the time $(\mathrm{T}) ; z$ is the vertical coordinate $(\mathrm{L})$ positive downward; $S(z, t)$ is the sink term for water uptake by plant that is a spatial and temporal function of root length and is expressed as the volume of water per unit volume of soil per unit time.

To solve the Richard's equation, the following constitutive relationships are required. Such relations were proposed by Van Genuchten (1980) and which are given in following equations:

$$
\begin{gathered}
S_{e}=\frac{\theta_{w}-\theta_{r}}{\theta_{s}-\theta_{r}} \\
\theta_{w}=\theta_{r}+\left[\frac{\theta_{s}-\theta_{r}}{1+(\alpha|h|) \beta}\right]^{\eta} \\
K(h)=K_{s} S_{e}^{1 / 2}\left[1-\left(1-S_{e}^{1 / \eta}\right)^{\eta}\right]^{2},
\end{gathered}
$$


where $\theta_{w}$ is the water content $\left(\mathrm{L}^{3} / \mathrm{L}^{3}\right) ; S_{e}$ is the effective saturation; $\theta_{s}$ is the saturated water content; $\theta_{r}$ is the residual water content; $K_{S}$ is the saturated hydraulic conductivity (L/T); $\alpha, \beta$ and $\eta$ are fitting parameters.

The chemical and biological reactions of nitrogen transformation in the soil when wastewater is applied are nitrification, denitrification, uptake of ammonium and nitrate by plants, and adsorption of ammonium on the soil cation exchange sites (Antonopoulos 1993) are shown in figure 3a. To simplify the model formulation, this section considered only ammonium nitrogen and nitrate nitrogen as the main nitrogen species along with adsorption process of ammonium nitrogen and nitrification along with denitrification are the key reactions in the nitrogen cycle.

The one-dimensional vertical mass transport and transformations of ammonium nitrogen and nitrate nitrogen under transient flow and variably saturated soil conditions are described in the following equations (Antonopoulos 1993):

$$
\begin{gathered}
\theta_{w} \frac{\partial \mathrm{NH}_{4}-\mathrm{N}}{\partial t}+\rho_{b} \frac{\partial s}{\partial t}=\frac{\partial}{\partial z}\left(\theta_{w} D \frac{\partial \mathrm{NH}_{4}-\mathrm{N}}{\partial z}\right)-q \frac{\partial \mathrm{NH}_{4}-\mathrm{N}}{\partial z}+Q_{\mathrm{am}}-\phi_{1} \\
\theta_{w} \frac{\partial \mathrm{NO}_{3}-\mathrm{N}}{\partial t}=\frac{\partial}{\partial z}\left(\theta_{w} D \frac{\partial \mathrm{NO}_{3}-\mathrm{N}}{\partial z}\right)-q \frac{\partial \mathrm{NO}_{3}-\mathrm{N}}{\partial z}+Q_{\mathrm{ni}}-\phi_{2}
\end{gathered}
$$
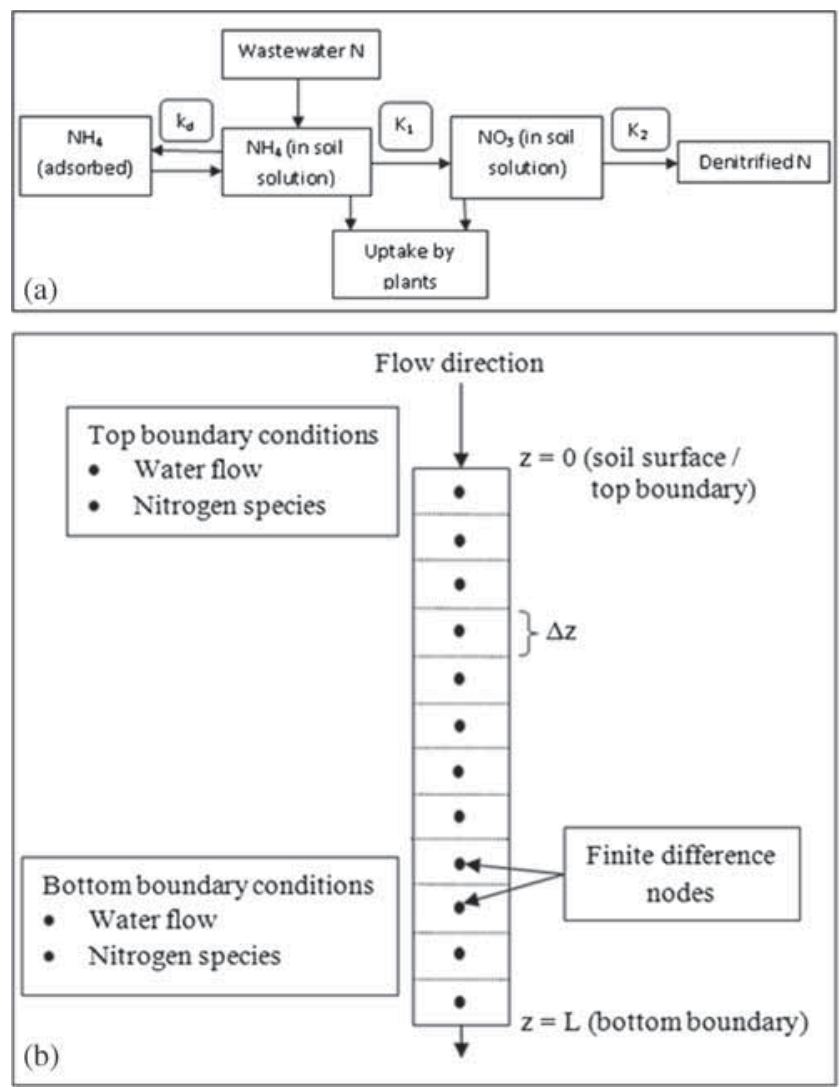

Figure 3. (a) Conceptual model for nitrogen cycle in soil-water system. (b) Graphical representation of finite difference cells and boundary conditions for one-dimensional domain. 
where $\mathrm{NH}_{4}-\mathrm{N}$ is the concentration of ammonium nitrogen; $\mathrm{NO}_{3}-\mathrm{N}$ is the concentration of nitrate nitrogen; $D=D_{m} * \tau+q * \alpha_{L}, D$ is the dispersion coefficient; $D_{m}$ is the molecular diffusion coefficient; $\tau$ is the tortuasity; $q$ is the Darcy velocity; $\alpha_{L}$ is the longitudinal dispersivity; $\rho_{b}$ is the bulk density of soil; $S$ ( $\left.S=K_{d} * \mathrm{NH}_{4}-\mathrm{N}\right)$ is the amount of $\mathrm{NH}_{4}-\mathrm{N}$ in the adsorbed phase per unit mass of soil; $K_{d}$ is the linear partitioning coefficient of ammonium nitrogen, $\Phi_{1}$ is the rate of $\mathrm{NH}_{4}-\mathrm{N}$ transformation per unit soil volume; $\Phi_{2}$ is the rate of $\mathrm{NO}_{3}-\mathrm{N}$ transformation per unit soil volume; $Q_{\text {am }}$ is the rate of plant uptake of $\mathrm{NH}_{4}-\mathrm{N}$ per unit soil volume and $Q_{\text {ni }}$ is the rate of plant uptake of $\mathrm{NO}_{3}-\mathrm{N}$ per unit soil volume. The plant uptake process is not considered in this study.

The transformation terms $\Phi_{1}$ and $\Phi_{2}$ describe the nitrification of $\mathrm{NH}_{4}-\mathrm{N}$ and denitrification of $\mathrm{NO}_{3}-\mathrm{N}$ which are approximated by first-order kinetic type reactions which are given in following equations (Antonopoulos 1993):

$$
\begin{gathered}
\phi_{1}=-K_{1} \theta_{w}\left(\mathrm{NH}_{4}-\mathrm{N}\right) \\
\phi_{2}=K_{1} \theta_{w}\left(\mathrm{NH}_{4}-\mathrm{N}\right)-K_{2} \theta_{w}\left(\mathrm{NO}_{3}-\mathrm{N}\right)
\end{gathered}
$$

where $K_{1}$ and $K_{2}$ are the nitrification and denitrification rates.

3.4a HYDRUS-1D software: HYDRUS-1D is freely available public domain windows-based computer software to model the water flow and solute transport in variably saturated porous media. The HYDRUS software will numerically solve the Richard's equation for unsaturated water flow and conventional convective-dispersion type equations for solute transport. Generally, the flow and contaminant transport equation accounts for water uptake by plant roots, linear and nonlinear reactions and first order degradations. This package deals with prescribed head and flux boundaries, boundaries controlled by atmospheric conditions, as well as free drainage boundary conditions for water flow model. The governing flow and transport equations are solved numerically using Galerkin-type linear finite element schemes. In order to check the developed numerical model the experimental results were analyzed with HYDRUS-1D software. Furthermore, various sensitivity analyses were also performed with this package for various irrigation scenarios and extreme case scenarios.

3.4b Numerical implementation: The coupled system of partial differential equations describing water flow and nitrogen species transport is solved numerically using fully implicit finite difference scheme. The advection part, which reflects the hyperbolic nature of the given partial differential equation is discretized using first order upwind scheme, while the dispersive part, which reflects the parabolic nature of the given partial differential equation is discretized using second order central difference scheme. The vertical one dimensional unsaturated spatial domain is divided into a finite number of discrete cells as shown in figure $3 \mathrm{~b}$. For temporal discretization, the total simulation time is divided into a finite number time intervals $(\Delta t)$. The value of cell width in the vertical direction $(\Delta z)$ is assumed to be $0.5 \mathrm{~cm}$ and the time interval $(\Delta t)$ is assumed to be $100 \mathrm{~s}$ in order to meet the numerical stability criteria. The resulting tri-diagonal matrix is solved using Thomas algorithm.

\section{Results and discussion}

For the purpose of understanding the nitrogen species transport in hydraulically varying field soil, the experimental and modeling of nitrogen species in Kancheepuram, Tamilnadu and Ludhiana, Punjab have been performed using laboratory scale soil column experiments and the corresponding numerical model was developed. Furthermore, HYDRUS-1D software also used to predict 
Table 1. Textile wastewater characteristics from Kancheepuram, Tamilnadu (average value).

\begin{tabular}{lcccccc}
\hline $\begin{array}{l}\text { Sample } \\
\text { collection point }\end{array}$ & BOD (mg/l) & COD $(\mathrm{mg} / \mathrm{l})$ & TDS $(\mathrm{mg} / \mathrm{l})$ & Turbidity (NTU) & pH & $\begin{array}{c}\text { Nitrate } \\
\text { nitrogen }(\mathrm{mg} / \mathrm{l})\end{array}$ \\
\hline Dye bath effluent 1 & 20 & 16,320 & 3492 & 322 & 7.602 & 98.04 \\
Dye bath effluent 2 & 700 & 32,000 & 2635 & 368 & 9.979 & 73.87 \\
Degumming water & 5120 & 9920 & 2437 & 530 & 10.829 & 53.47 \\
Wash water & 400 & 2880 & 1577 & 83 & 7.998 & 63.71 \\
Combined effluent & 290 & 19,960 & 3840 & 124 & 7.949 & 92.62 \\
\hline
\end{tabular}

the nitrogen species concentrations. This section discusses the experimental and modeling results on nitrogen species transport under various irrigation scenarios according to the crops requirement.

\subsection{Wastewater characteristics}

The wastewater samples collected from different points of textile industry in Kancheepuram, Tamilnadu were analyzed as per the standard laboratory analytical methods. The results of various parameters of Kancheepuram wastewater samples are shown in table 1. Similarly, the wastewater collected from various points of treatment plant in Ludhiana, Punjab was characterized and is presented in table 2 .

Tables 1 and 2 show the characteristics of wastewater from textile industries located at Kancheepuram, Tamilnadu and Ludhiana, Punjab. Since there are no proper treatment technologies adopted in Kancheepuram, the wastewater generated from the textile industries was discharged on the bare land without proper treatment. In Ludhiana, the majority of the textile industries have their own treatment plant for wastewater treatment. The wastewater generated from Kancheepuram textile industries shows that the BOD, COD and TDS are very high as compared with the CPCB (Paul et al 2012) standards except pH value. Similarly, the parameters measured in the wastewater generated from Ludhiana were also high compared to the CPCB standards except TDS and $\mathrm{pH}$. However, the treated effluent of Ludhiana wastewater was within the CPCB standards.

\subsection{Physical and chemical characteristics of soil}

The particle size distribution of Kancheepuram and Ludhiana soil is shown in figure 4.

The soil analysis results show that the bulk density of Kancheepuram soil $\left(1.918 \mathrm{~g} / \mathrm{cm}^{3}\right) \mathrm{sam}$ ple is lesser than that of Ludhiana soil $\left(2.221 \mathrm{~g} / \mathrm{cm}^{3}\right)$. This may be due to the variation in grain size distribution of soil, whereas the specific gravity value did not vary significantly. The porosity

Table 2. Textile wastewater characteristics from Ludhiana, Punjab (average value).

\begin{tabular}{lcccccc}
\hline $\begin{array}{l}\text { Sample } \\
\text { collection point }\end{array}$ & \multicolumn{1}{c}{} & & \multicolumn{3}{c}{ Nitrate } \\
& BOD (mg/l) & COD (mg/l) & TDS (mg/l) & Turbidity (NTU) & pH & nitrogen (mg/l) \\
\hline Influent to treatment plant & 145.3 & 1800 & 974 & 58.77 & 7.3 & 64 \\
Biological tank & 122 & 1197 & 959 & 259.4 & 6.67 & 13.59 \\
Sedimentation tank & 64.6 & 264 & 952 & 14.67 & 6.69 & 18 \\
Outlet from treatment plant & 30.6 & 123 & 854 & 4.75 & 6.67 & 7 \\
\hline
\end{tabular}




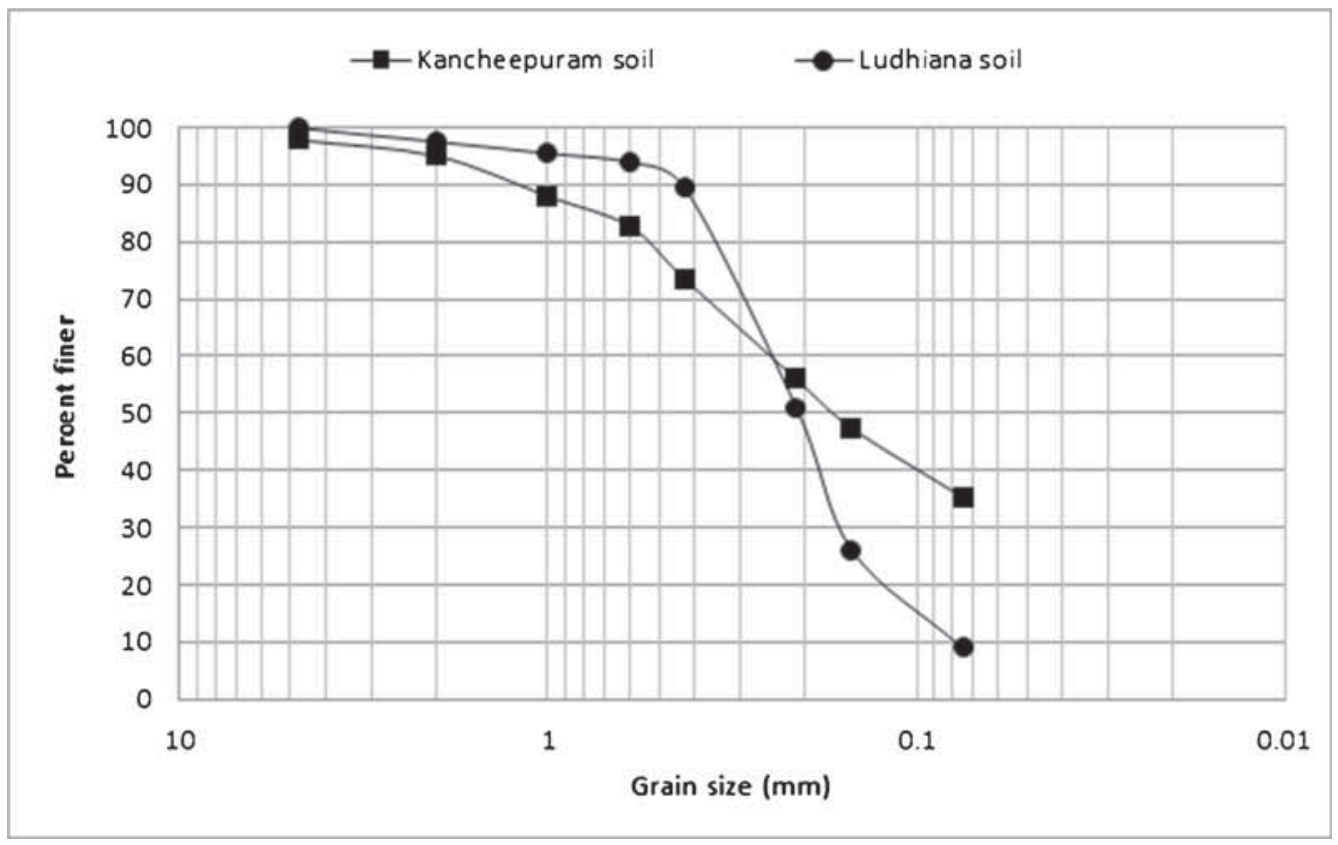

Figure 4. Particle size distribution of (A) Kancheepuram and (B) Ludhiana soil (for size greater than 75 microns).

value of Kancheepuram soil was higher than the porosity of Ludhiana soil. This high porosity is mainly due to the high clay and silt content in Kancheepuram soil which is shown in figure 4. Kancheepuram soil consists of the gravel $(>4.75 \mathrm{~mm})$, sand $(4.75-0.075 \mathrm{~mm})$ and silt with clay $(<0.075 \mathrm{~mm})$ fractions which are 2.2, 62.5 and $35.3 \%$ respectively (figure 4). Similarly, Ludhiana soil consists of the gravel $(>4.75 \mathrm{~mm})$, sand $(4.75-0.075 \mathrm{~mm})$ and silt with clay $(<0.075 \mathrm{~mm})$ fractions, which are $0.1,90.6$ and $9.3 \%$ respectively of the total mass of the soil (figure 4 ). An order of reduction in permeability was observed for Ludhiana soil $\left(3.9 \times 10^{-4} \mathrm{~cm} / \mathrm{s}\right)$ due to high sand content when compared with Kancheepuram $\left(6.0 \times 10^{-5} \mathrm{~cm} / \mathrm{s}\right)$ soil. The high percentage of silt and clay in Kancheepuram soil plays a predominant role on permeability reduction. Since the soil samples were taken from irrigation field, the carbon content $(1,933 \mathrm{mg} / \mathrm{kg}$ for Kancheepuram and 1,794 for Ludhiana soil), ammonium nitrogen $(5 \mathrm{mg} / \mathrm{kg}$ for Kancheepuram and 2 for Ludhiana soil) and nitrate nitrogen ( $15 \mathrm{mg} / \mathrm{kg}$ for Kancheepuram and 60 for Ludhiana soil) are on the higher side. It is also observed that both soil samples were relatively in basic range $(\mathrm{pH}$ 8.81 for Kancheepuram and 7.8 for Ludhiana soil).

\subsection{Estimation of Van Genuchten parameters}

Van Genuchten parameters are the useful data required to model the water flow in order to relate the water content, pressure head and hydraulic conductivity for unsaturated soil system. These parameters can be obtained by the relation between water content, pressure head and unsaturated hydraulic conductivity using RETC software (Van Genuchten et al 1991). RETC is computer software which is used to analyze the soil water retention and hydraulic conductivity relations of unsaturated soil developed by PC-PROGRESS engineering software developer group. Before running the RETC software, it is required to find the various water contents for the corresponding 
Table 3. Measured water content and corresponding pressure head for Kancheepuram and Ludhiana soil.

\begin{tabular}{|c|c|c|c|c|}
\hline \multirow[b]{2}{*}{ Sl. No. } & \multicolumn{2}{|c|}{ Kancheepuram soil } & \multicolumn{2}{|c|}{ Ludhiana soil } \\
\hline & $\begin{array}{l}\text { Pressure applied } \\
\left(\mathrm{cm} \text { of } \mathrm{H}_{2} \mathrm{O}\right)\end{array}$ & $\begin{array}{c}\text { Average water } \\
\text { content }\left(\mathrm{cm}^{3} / \mathrm{cm}^{3}\right)\end{array}$ & $\begin{array}{l}\text { Pressure applied } \\
\left(\mathrm{cm} \text { of } \mathrm{H}_{2} \mathrm{O}\right)\end{array}$ & $\begin{array}{c}\text { Average water } \\
\text { content }\left(\mathrm{cm}^{3} / \mathrm{cm}^{3}\right)\end{array}$ \\
\hline 1 & 10197 & 0.1151 & 12236.4 & 0.03375 \\
\hline 2 & 7137.9 & 0.1305 & 9177.3 & 0.03713 \\
\hline 3 & 4078.8 & 0.1528 & 6118.2 & 0.04485 \\
\hline 4 & 3059.1 & 0.1622 & 4078.8 & 0.04672 \\
\hline 5 & 2039.4 & 0.1808 & 3059.1 & 0.04089 \\
\hline 6 & 1526.55 & 0.1841 & 2039.4 & 0.05118 \\
\hline 7 & 1121.67 & 0.2436 & 1529.55 & 0.06684 \\
\hline 8 & 815.76 & 0.2254 & 1019.7 & 0.06880 \\
\hline 9 & 611.82 & 0.2508 & 611.82 & 0.07132 \\
\hline 10 & 305.91 & 0.2757 & 203.94 & 0.10283 \\
\hline 11 & 0 & 0.4204 & 0 & 0.26188 \\
\hline
\end{tabular}

pressure head. Pressure plate apparatus was used to obtain the data set between water content and corresponding pressure head. The data obtained from pressure plate apparatus for Kancheepuram and Ludhiana soil samples are given in table 3.

After obtaining the pressure head and water content data using pressure plate apparatus, the measured pressure head and corresponding water contents were fed into the RETC software to derive the retention curve and to find the van Genuchten parameters. The resulting retention curve for Kancheepuram and Ludhiana soil is shown in figure 5 with $R^{2}$ value for regression of observed and fitted values was 0.96 and 0.99 respectively. The predicted soil hydraulic parameters of Kancheepuram and Ludhiana soil are shown in table 4.

The predicted value of van Genuchten parameter $\alpha$ for Kancheepuram soil is one order of magnitude lesser than Ludhiana soil. This has a significant impact on the unsaturated hydraulic properties such as water content, pressure head and hydraulic conductivity. The other van Genuchten parameter $\beta$ has a marginal change in the magnitude for both soils. Since the soil hydraulic parameters are non-linearly related, a small change in the van Genuchten parameters also has a significant impact on soil hydraulic properties. These predicted parameters are used in

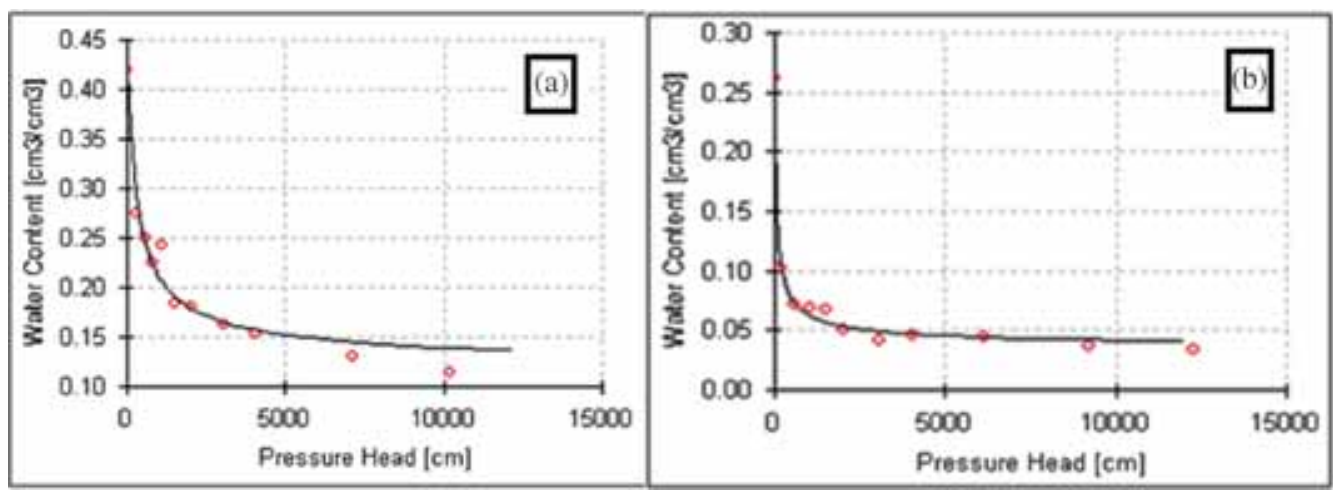

Figure 5. Pressure head vs water content profile from RETC software for (A) Kancheepuram and (B) Ludhiana (symbol - measured and line - fitted). 
Table 4. Predicted values of soil hydraulic properties from RETC software.

\begin{tabular}{lcc}
\hline Parameter & Kancheepuram soil & Ludhiana soil \\
\hline Saturated water content & 0.41814 & 0.26485 \\
Van Genuchten parameter $(\alpha)\left(\mathrm{cm}^{-1}\right)$ & 0.00636 & 0.03611 \\
Van Genuchten parameter $(\beta)$ & 1.6075 & 1.5748 \\
\hline
\end{tabular}

the developed numerical and HYDRUS-1D model to simulate the nitrogen species transport in the soil columns.

\subsection{Column experimental results with model validation}

An experimental investigation and numerical validation for nitrogen species using synthetic wastewater for Kancheepuram and Ludhiana soils have been performed. No effluent was collected at the bottom of the soil column during groundnut irrigation simulation Kancheepuram soil due to very low permeability and split application. On the other hand, the effluent was collected only during the wastewater applied period except first irrigation due to high permeability of Ludhiana soil for wheat irrigation. However, the concentration of ammonium and nitrate nitrogen in the effluent of wheat irrigation was comparatively low with paddy irrigation. Therefore, the numerical simulations were performed only for paddy irrigation for both Kancheepuram and Ludhiana soils. The van Genuchten parameters $(\alpha, \beta, \eta)$, other soil hydraulic parameters and nitrogen transformation rates for Kancheepuram and Ludhiana soil are given in table 5 .

Figures 6 and 7 show the experimental and numerical validation of ammonium nitrogen and nitrate nitrogen concentration at the bottom of the soil column (at $55 \mathrm{~cm}$ from soil surface) with similar conditions in Kancheepuram field. Initially the soil was assumed to be dry and the corresponding water content $\left(\theta \approx 0.12 \mathrm{~cm}^{3} / \mathrm{cm}^{3}\right)$ was assigned as the initial condition for water flow model. Since the paddy field was flooded with water throughout the crop life, the corresponding water content $\left(\theta \approx 0.41 \mathrm{~cm}^{3} / \mathrm{cm}^{3}\right)$ was assumed as the top boundary condition and the zero flux is used as the bottom boundary condition for water flow model. At the start of the numerical simulation, the soil was assumed to be free from contaminants, and subsequently the initial ammonium and nitrite nitrogen concentrations were assumed to be zero except at the top of the soil. A constant concentration of $50 \mathrm{mg} / \mathrm{l}$ of ammonium nitrogen and $20 \mathrm{mg} / \mathrm{l}$ of nitrate nitrogen

Table 5. Soil hydraulic parameters and nitrogen transformation rates for Kancheepuram and Ludhiana soil.

\begin{tabular}{|c|c|c|c|}
\hline Parameter & Kancheepuram soil & Ludhiana soil & Source \\
\hline Depth of column $(\mathrm{cm})$ & 55 & 55 & \\
\hline Saturated water content $\left(\mathrm{m}^{3} / \mathrm{m}^{3}\right)$ & 0.4181 & 0.2649 & Measured \\
\hline Residual water content $\left(\mathrm{m}^{3} / \mathrm{m}^{3}\right)$ & 0.115 & 0.0335 & Measured \\
\hline Saturated hydraulic conductivity $(\mathrm{cm} /$ day) & 5.184 & 33.57 & Measured \\
\hline Van Genuchten parameter $(\alpha)\left(\mathrm{cm}^{-1}\right)$ & 0.00636 & 0.03611 & From RETC \\
\hline Van Genuchten parameter $(\beta)$ & 1.60749 & 1.575 & From RETC \\
\hline Soil bulk density $(\mathrm{mg} / \mathrm{l})$ & $1.91 \times 10^{6}$ & $2.22 \times 10^{6}$ & Measured \\
\hline $\begin{array}{l}\text { Linear partitioning coefficient of } \\
\text { ammonium nitrogen }(1 / \mathrm{mg})\end{array}$ & $3.4 \times 10^{-7}$ & $6.4 \times 10^{-7}$ & From HYDRUS-1D \\
\hline Nitrification rate $\left(\right.$ day $\left.^{-1}\right)$ & 0.4 & 0.45 & From HYDRUS-1D \\
\hline Denitrification rate $\left(\right.$ day $\left.^{-1}\right)$ & 0.3 & 0.04 & From HYDRUS-1D \\
\hline
\end{tabular}




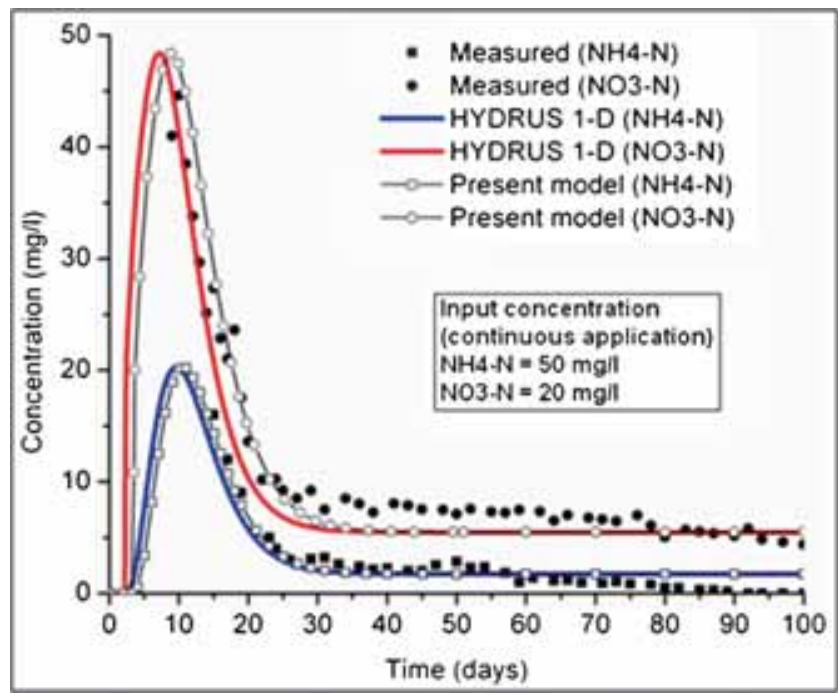

Figure 6. Temporal variation of nitrogen species concentration for Kancheepuram soil using HYDRUS 1-D and developed model in soil column\#1.

were applied in influent solution at the top of the soil column. The concentration gradient for all nitrogen species is assumed to be at zero for the bottom boundary condition (Lee et al 2006). Measureable quantity of wastewater was collected at the bottom of the soil column only after 9 days and the corresponding nitrogen species concentrations are shown in figures 7 and 10 . The initial delay in arrival of effluent at the bottom of the soil column is mainly due to the dry condition of the soil and very low hydraulic conductivity (measured hydraulic conductivity was $5.184 \mathrm{~cm} /$ day). The maximum concentration of $20 \mathrm{mg} / \mathrm{l}$ of ammonium nitrogen and nearly 50

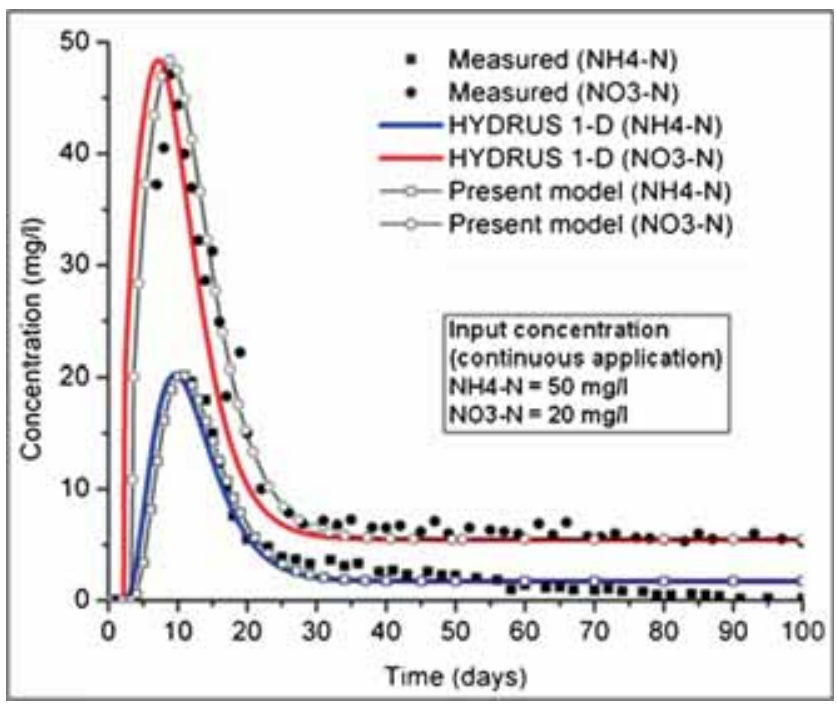

Figure 7. Temporal variation of nitrogen species concentration for Kancheepuram soil using HYDRUS 1-D and developed model in soil column\#2. 
$\mathrm{mg} / \mathrm{l}$ of nitrate nitrogen was observed at the end of $10^{\text {th }}$ day. To validate the developed model the numerical analysis was performed with the measured soil hydraulic parameters. The optimum values of linear partitioning coefficient of ammonium nitrogen, nitrification rate and denitrification rate were obtained from the simulated concentration profile of ammonium nitrogen and nitrate nitrogen, which showed a good match with the experimental data.

The applied ammonium nitrogen was converted to nitrate nitrogen due to nitrification and this phenomenon was observed from both soil column data (figures 6 and 7). However, the concentration of ammonium nitrogen decreased after 10 days and reached the asymptotic stage only after 30 days. The similar trend was also observed for nitrate nitrogen profile with higher concentration as compared with ammonium nitrogen. Since the predicted nitrification rate $(0.4$ per day) was little higher than the denitrification rate ( 0.3 per day), the peak as well as the asymptotic stage concentration of nitrate nitrogen was always higher than the ammonium nitrogen concentration in the aqueous phase. Although the predicted nitrification rate for Kancheepuram soil ( $K_{1}=0.4$ per day) is almost similar which is reported by Kaluarachchi \& Parker (1988), the denitrification rate is approximately one order higher in the current study as compared with the published data (Kaluarachchi \& Parker 1988). This may be due to the large residence time for denitrification attributed to the higher clay content in the Kancheepuram soil, whereas Kaluarachchi \& Parker (1988) observed less denitrification rate and less residence time in sandy soil. The experimental data were further simulated with HYDRUS-1D software and the simulated results were in good agreement with the observed data.

Figures 8 and 9 show the experimental and numerical verification of ammonium nitrogen and nitrate nitrogen concentration at the bottom of the soil column (at $55 \mathrm{~cm}$ from soil surface) with similar conditions in Ludhiana field. Based on the $\mathrm{NH}_{4}-\mathrm{N}$ and $\mathrm{NO}_{3}-\mathrm{N}$ concentration in treated and untreated wastewater, different synthetic wastewater were prepared with low and high concentrations of $\mathrm{NH}_{4}-\mathrm{N}$ and $\mathrm{NO}_{3}-\mathrm{N}$ and experimented with the column containing soil from Ludhiana. The initial soil condition was assumed to be dry and the corresponding water content $\left(\theta \approx 0.04 \mathrm{~cm}^{3} / \mathrm{cm}^{3}\right)$ was assigned as the initial condition for water flow model. The saturated water content $\left(\theta \approx 0.25 \mathrm{~cm}^{3} / \mathrm{cm}^{3}\right)$ was assumed as the top boundary condition and the zero

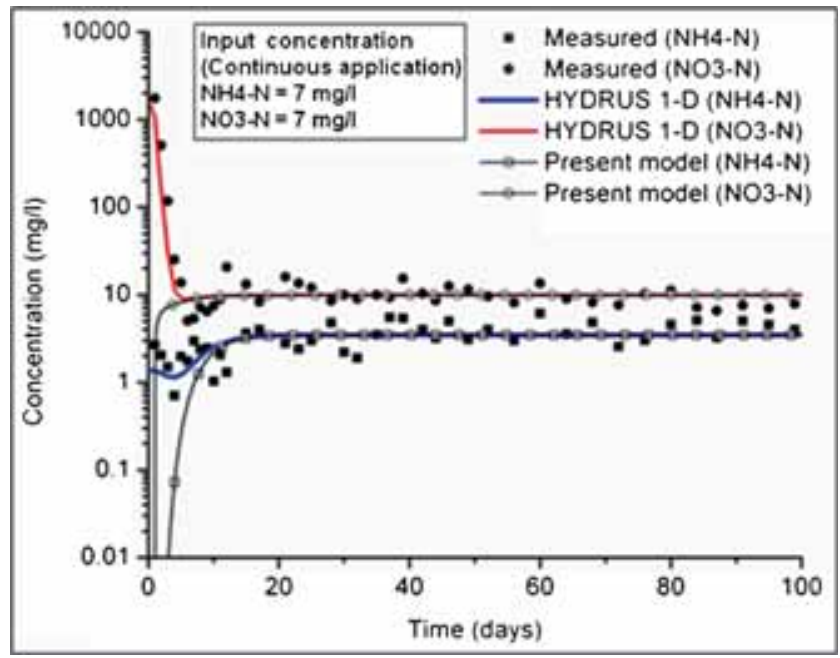

Figure 8. Temporal variation of nitrogen species concentration for Ludhiana soil using HYDRUS 1-D and developed model in soil column with low influent concentration. 


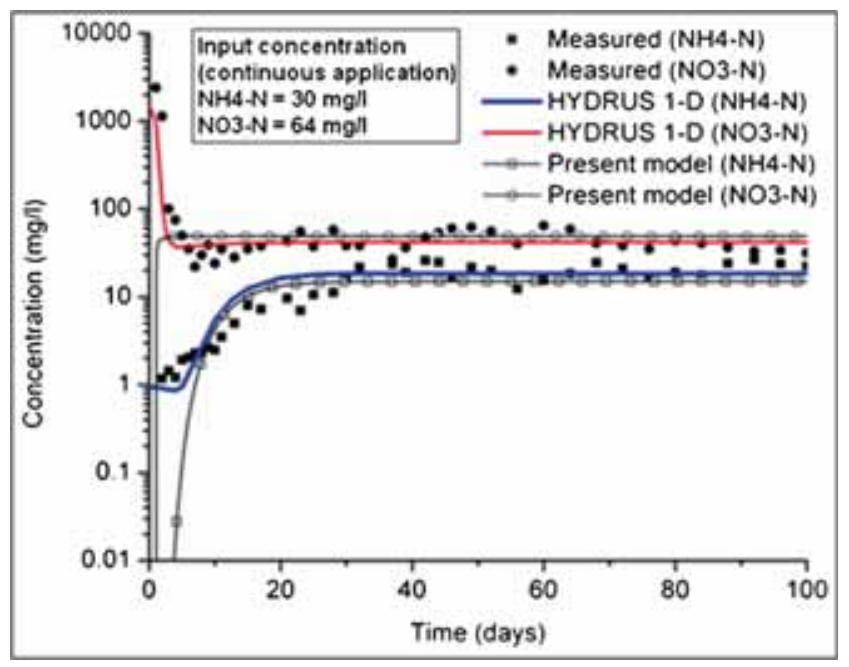

Figure 9. Temporal variation of nitrogen species concentration for Ludhiana soil using HYDRUS 1-D and developed model in soil column with high influent concentration.

flux is used as the bottom boundary condition for water flow model. At the start of the numerical simulation, the background ammonium and nitrate nitrogen concentration was assumed to be 2 $\mathrm{mg} / \mathrm{kg}$ and $60 \mathrm{mg} / \mathrm{kg}$ for HYDRUS simulation. A constant concentration of $7 \mathrm{mg} / \mathrm{l}$ of ammonium nitrogen and $7 \mathrm{mg} / \mathrm{l}$ of nitrate nitrogen was applied in influent solution at the top of the soil column as a treated wastewater scenario, whereas $30 \mathrm{mg} / \mathrm{l}$ of ammonium nitrogen and 64 $\mathrm{mg} / \mathrm{l}$ of nitrate nitrogen were applied in another column as an untreated wastewater scenario. The concentration gradient for all nitrogen species is assumed to be at zero for the bottom boundary condition. Figure 8 shows the concentration profile for Ludhiana soil with low (treated wastewater) influent contaminant concentration. Figure 8 illustrates that the observed concentration of ammonium nitrogen at the bottom of the soil column follows a significant decreasing trend up to nearly five days. This initial high concentration is contributed from the background soil concentration which is dissolved initially in aqueous phase due to the high concentration gradient. Later (on $5^{\text {th }}$ day), the ammonium nitrogen concentration started increasing and reaches the maximum concentration after 30 days. Similarly, the nitrate nitrogen concentration in the aqueous phase is observed to be very high at initial time due to elevated background concentration on nitrate nitrogen $(60 \mathrm{mg} / \mathrm{kg})$ in soil. However, the nitrate nitrogen concentration in the later stage was controlled by the influent concentration given in the top of the soil column along with the transformation and sorption processes. Moreover, the results show that high concentration of $\mathrm{NH}_{4}-\mathrm{N}$ is observed in the infiltrating water. This can lead to contaminate the neighboring surface water body such as lakes, ponds due to the lateral seepage process. It is toxic to fish if the $\mathrm{NH}_{4}-\mathrm{N}$ concentration is higher than $4 \mathrm{mg} / \mathrm{l}$. The HYDRUS-1D simulated profile was in good agreement with measured ammonium and nitrate nitrogen concentrations. The developed model was also able to predict both nitrogen species concentrations except during the initial simulation time. Since the developed model did not have any term to compute the aqueous concentration from huge background soil nitrogen concentration, the simulated results were not accounting the addition on nitrogen species concentration in the aqueous phase from solid phase nitrogen concentration in soil. The nitrification and denitrification values predicted by the HYDRUS-1D model for Ludhiana soil are nearly similar to Kaluarachchi \& Parker (1988) reported values. 
This confirms that the HYDRUS-1D and developed model were predicting the nitrogen species concentrations well for Ludhiana soil. Figure 9 shows the concentration profile for Ludhiana soil with high (untreated wastewater) influent contaminant concentration. The other physical, chemical and biological conditions were similar to low influent contaminant concentration column experiments. The predicted concentrations by HYDRUS-1D and developed model were in good agreement with the observed data except for initial prediction by developed model.

Figure 10 shows the concentration variation of nitrogen species for Ludhiana soil for wheat irrigation scenario with untreated wastewater application. The wastewater was applied only at the scheduled times with the limited quantity (1,063 ml per day) which was calculated as per the guidelines given by Tamilnadu Agricultural University. The effluent was collected at the bottom of the column only when the wastewater was applied at the top of the soil column. However, measurable water was not collected at the bottom of the column during the first $\left(1^{\text {st }}\right.$ day) irrigation due to initial dry condition of soil. It is observed from figure 10 that the ammonium nitrogen concentration profile was following a small decreasing trend and increasing trend thereafter. The initial high concentration is due to the background soil concentration and the higher concentration in the later stage is due to the wastewater irrigation. Similarly, very high concentration (approximately 1,400 mg/l) of nitrate nitrogen was observed during second irrigation due to the background soil nitrogen concentration. Conversely, the concentration of nitrate nitrogen is following a continuous reduction tendency in the later time due to the intermittent wastewater application scenario which gives enough time for biodegradation. In both figures 9 and 10 for high input concentration under the soil condition in Ludhiana, it can be noted that ammonium nitrogen not completely degraded and is above the permissible level which is of concern.

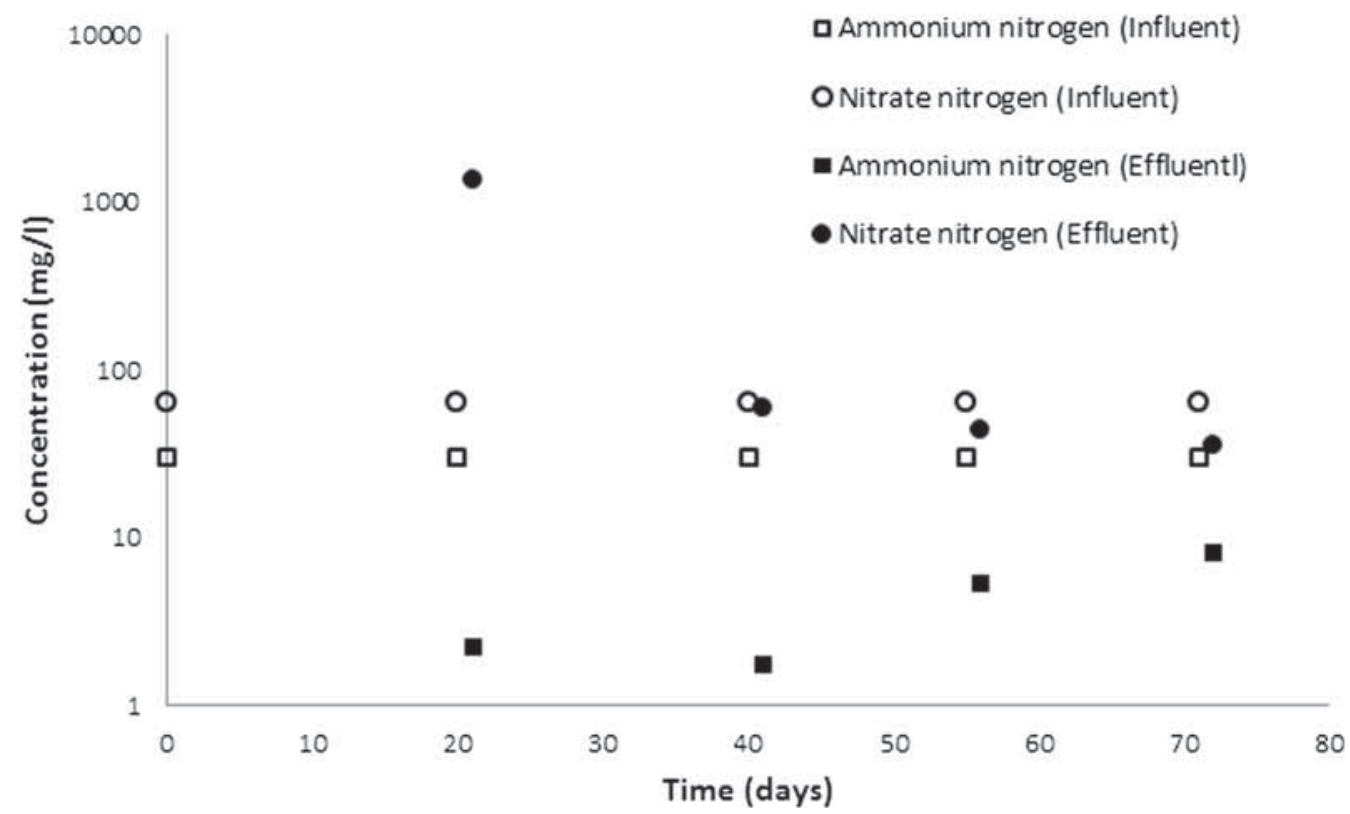

Figure 10. Temporal variation of nitrogen species concentration for Ludhiana soil for wheat irrigation scenario. 


\subsection{Sensitivity analysis}

Figure 11 shows the concentration profile of ammonium nitrogen and nitrate nitrogen for various linear partitioning coefficient of ammonium nitrogen in Kancheepuram soil. The base linear partitioning coefficient of ammonium nitrogen was predicted by the developed and HYDRUS1D model as $3.4 \times 10^{-7} \mathrm{l} / \mathrm{mg}$. When the linear partitioning coefficient was decreased by one order, the peak concentration of both nitrogen species was observed earlier as compared with the peak corresponding to the base value $\left(3.4 \times 10^{-7} \mathrm{l} / \mathrm{mg}\right)$. This shift of peak is due to low retardation of ammonium nitrogen. Similarly, it was observed that the change in nitrate nitrogen due to the transformation of ammonium nitrogen by nitrification process. In the same way, a drastic reduction of peak on ammonium nitrogen concentration was observed when the linear partitioning coefficient was increased one order from base value $\left(3.4 \times 10^{-7} 1 / \mathrm{mg}\right)$. This implies that increasing the retardation factor increased the delay of the peak value of ammonium and the corresponding nitrate nitrogen concentration. However the value of linear partitioning coefficient of ammonium nitrogen was a good match for $3.4 \times 10^{-7} 1 / \mathrm{mg}$ (base value) with observed ammonium nitrogen and nitrate nitrogen profiles.

Figure 12 provides the sensitivity of nitrification rate on ammonium nitrogen and nitrate nitrogen concentrations in Kancheepuram soil. The optimized value of nitrification rate obtained from developed and HYDRUS-1D model was 0.4 per day and the sensitivity analysis was performed for two higher and two lower rates from the optimized value. High concentration of ammonium nitrogen was observed in figure 12 at low nitrification rate which implies that the conversion of ammonium nitrogen to nitrate nitrogen was decreased and ammonium nitrogen concentration got accumulated in the system. On the other hand, the nitrate nitrogen concentration was reduced during low nitrification rate. Since the high nitrification rate enhances the conversion of ammonium nitrogen to nitrate nitrogen, a significant amount of nitrate nitrogen was observed during high nitrification rate.

Figure 13 shows the significance of denitrification rate on ammonium and nitrate nitrogen concentration in Kancheepuram soil. The results show that the denitrification rate does not affect the ammonium nitrogen concentration. Denitrification is done by mostly heterotrophs, which do not depend on carbon source and are slow growing. It can increase diffusion rates due to high concentration gradient locally caused by depletion of nitrate nitrogen. But this does not have
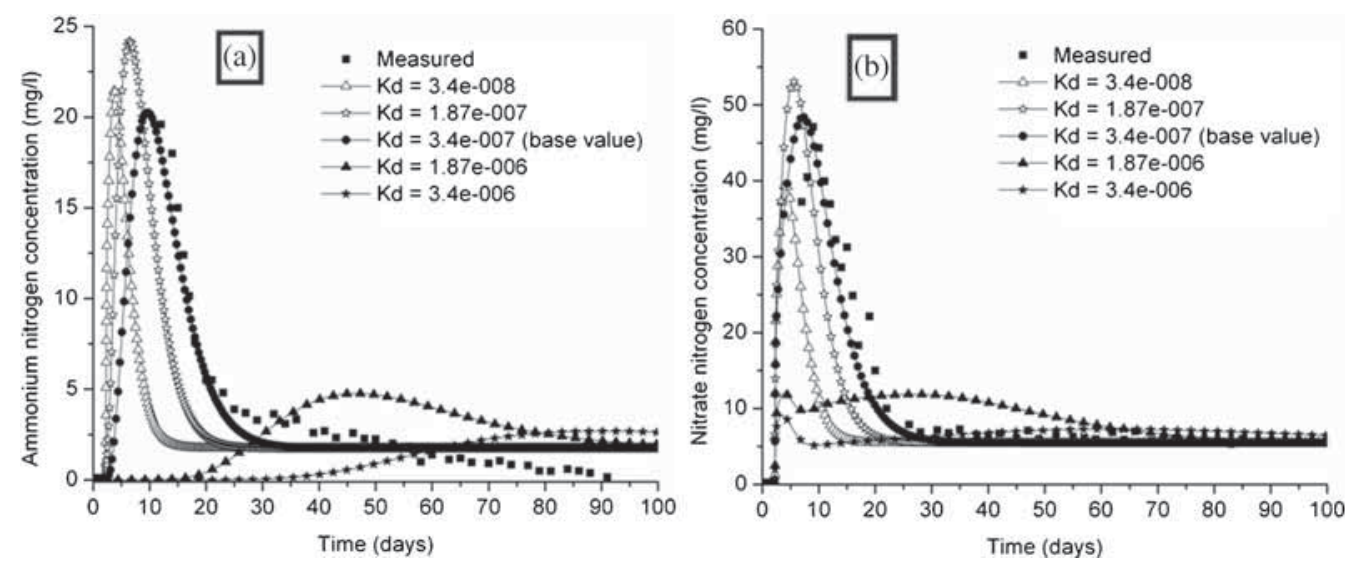

Figure 11. Sensitivity of adsorption rate $\left(K_{d}\right.$ in $\left.1 / \mathrm{mg}\right)$ on ammonium nitrogen concentration in (A) Kancheepuram and (B) Ludhiana soil. 

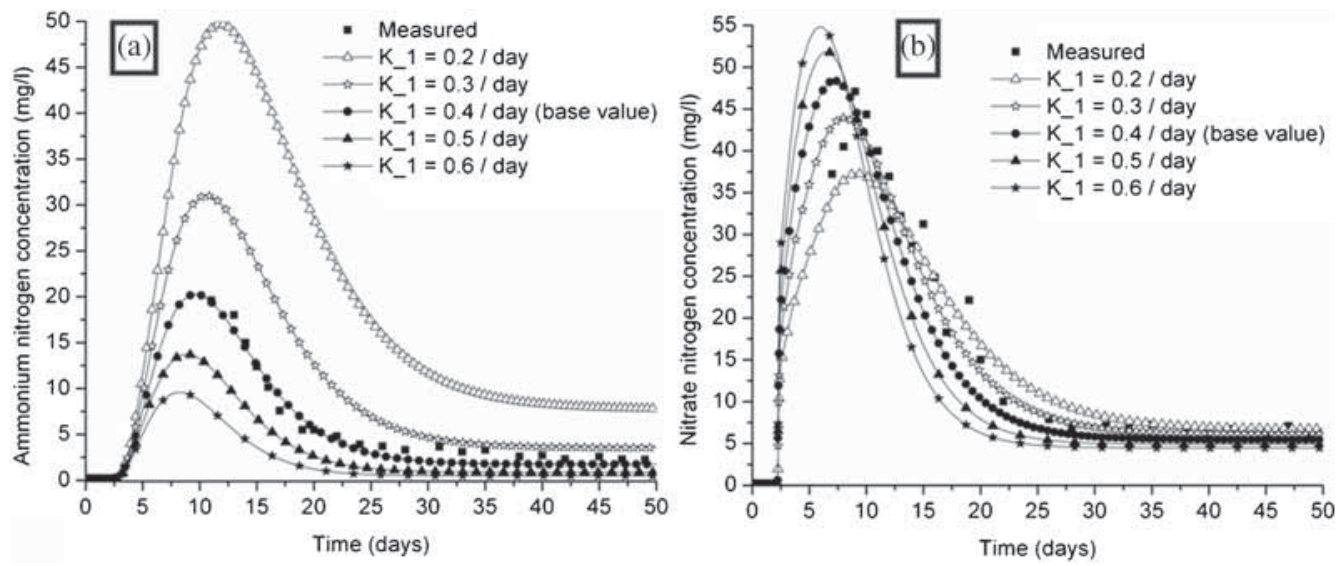

Figure 12. Sensitivity of nitrification rate $\left(K_{1}\right)$ on ammonium nitrogen concentration in (A) Kancheepuram and (B) Ludhiana soil.

any impact on ammonium nitrogen concentration even for huge changes in denitrification rate, which is shown in figure 13. Conversely, a considerable change in the concentration profile for nitrate nitrogen was observed for various denitrification rates. The peak concentration of $25 \mathrm{mg} / \mathrm{l}$ was observed for 0.5 per day of denitrification rate; while at denitrification rate of 0.1 per day increase in the nitrate nitrogen concentration was observed to be $100 \mathrm{mg} / \mathrm{l}$. Hence, these low denitrification rates can increase the nitrate nitrogen concentration in the aqueous phase which eventually brings down the groundwater quality.

Figure 14 illustrates the variation of linear partitioning coefficient of ammonium nitrogen on nitrogen species for Ludhiana soil. Figure 14 shows a significant variation on ammonium nitrogen concentration for different linear partitioning coefficient, whereas the corresponding change in the nitrate nitrogen concentration was nullified due to the large background concentration in soil. A significant change in nitrate nitrogen due to different linear partitioning coefficient of ammonium nitrogen was clearly observed in the case of soil which was free from contamination

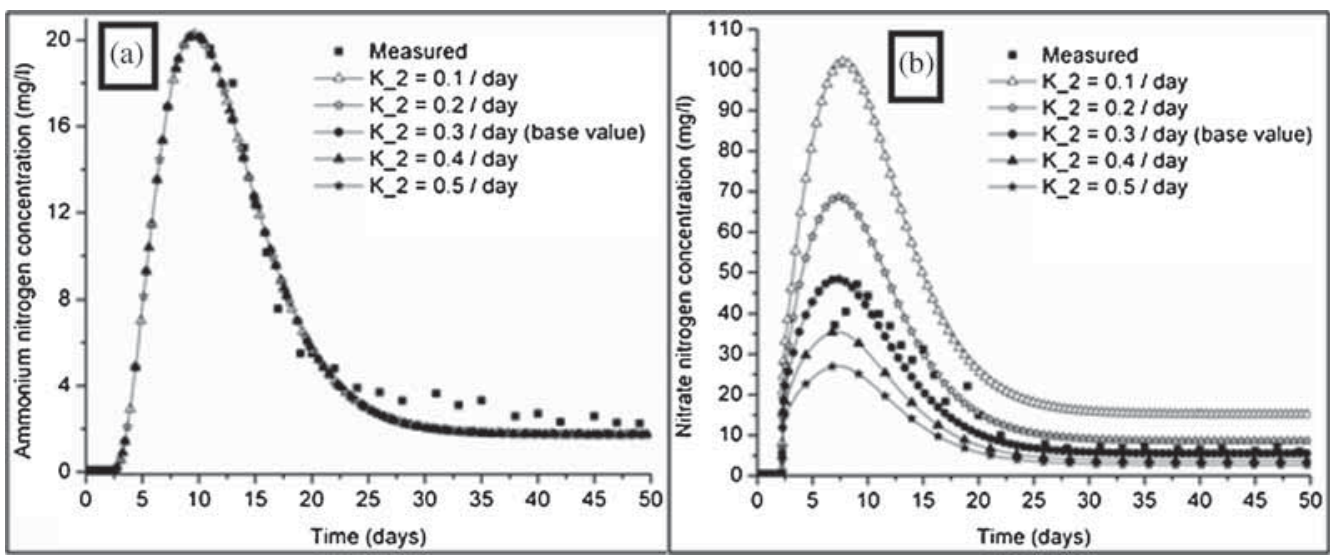

Figure 13. Sensitivity of denitrification rate $\left(K_{2}\right)$ on ammonium nitrogen concentration in (A) Kancheepuram and (B) Ludhiana soil. 


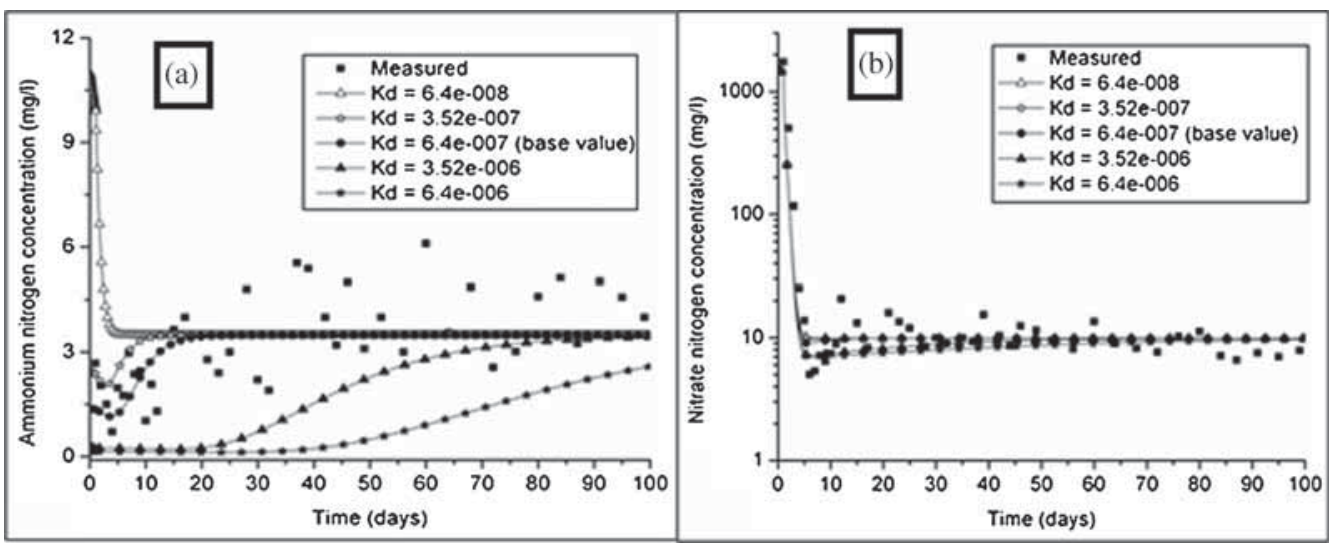

Figure 14. Sensitivity of adsorption rate $\left(K_{d}\right.$ in $\left.1 / \mathrm{mg}\right)$ on ammonium nitrogen concentration in (A) Kancheepuram and (B) Ludhiana soil.

(figure 11). The nitrification rate varying from 0.25 to 0.65 per day shows the concentration variation for ammonium nitrogen between 4.5 and $2.5 \mathrm{mg} / \mathrm{l}$ and for nitrate nitrogen between 8 and $11 \mathrm{mg} / \mathrm{l}$ (figure 15) in Ludhiana soil. However a considerable variation on ammonium nitrogen and nitrate nitrogen concentration (figure 12) was observed in clay rich Kancheepuram soil for various nitrification rates. This substantial variation is due to the large residence time by reduced hydraulic conductivity in Kancheepuram soil, while the residence time was very less for Ludhiana soil due to high permeability. Similar variation was also observed in nitrate nitrogen concentration due to the change in the denitrification rates (figure 16). Since denitrification process is performed by different groups of bacteria mostly heterotrophs, which convert the nitrate nitrogen to nitrogen gas, there is no impact on ammonium nitrogen concentration for any change in denitrification rate, which is shown in figure 16.
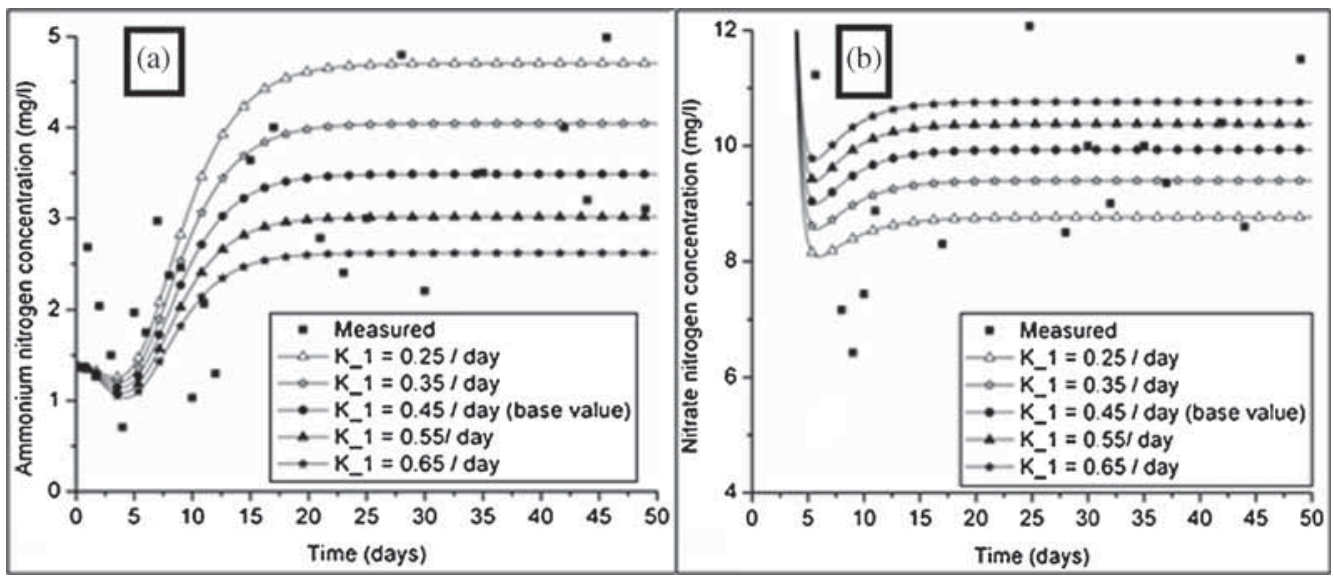

Figure 15. Sensitivity of nitrification rate $\left(K_{1}\right)$ on ammonium nitrogen concentration in (A) Kancheepuram and (B) Ludhiana soil. 


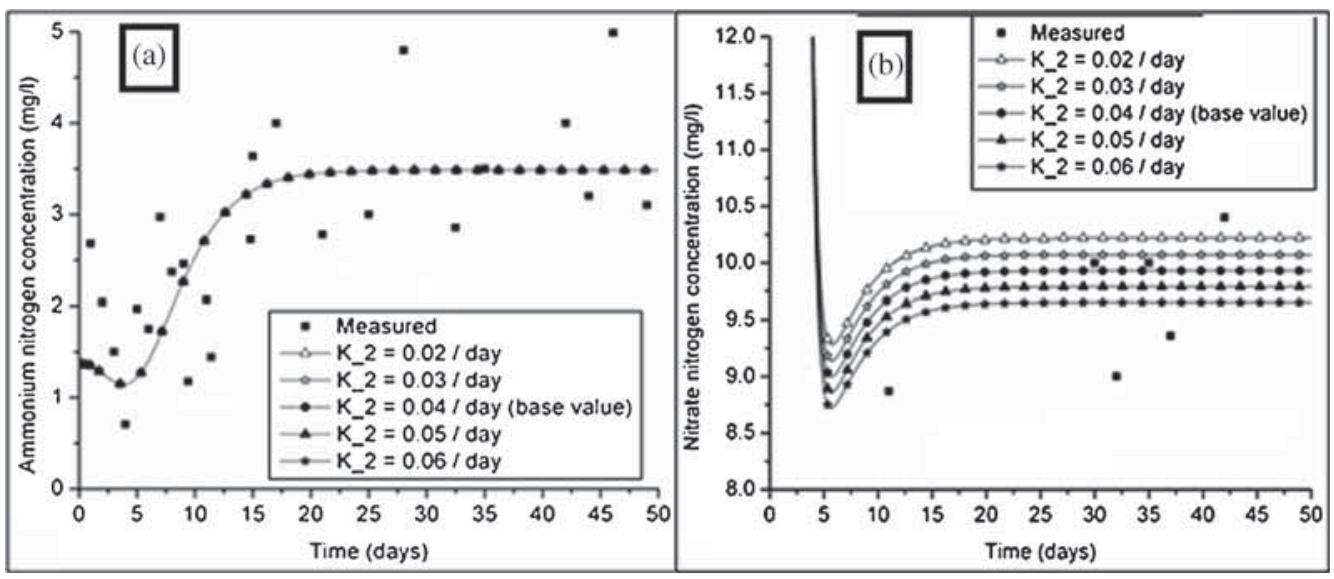

Figure 16. Sensitivity of denitrification rate $\left(\mathrm{K}_{2}\right)$ on ammonium nitrogen concentration in (A) Kancheepuram and (B) Ludhiana soil.

\subsection{Extreme case analysis}

In order to understand the severity of nitrogen species in groundwater resource during the wastewater application for agriculture, the developed numerical model was performed for various extreme influent concentrations in Kancheepuram and Ludhiana soil for 100 days of paddy irrigation. Initially, the soil was assumed to be free from nitrogen contamination in all extreme case analysis. The concentration of ammonium and nitrate nitrogen at different depths for various influent concentrations in Kancheepuram and Ludhiana soil are shown in tables 6 and 7 respectively. This will provide us the information on which locations are at high risk of groundwater contamination depending on the groundwater table depths.

It is observed from table 6 that the nitrate nitrogen concentration was above the allowable limit $(10 \mathrm{mg} / \mathrm{l})$ approximately up to $250 \mathrm{~cm}$ depth when the total (ammonium-nitrogen and nitrate nitrogen) nitrogen applied was $70 \mathrm{mg} / \mathrm{l}$ irrespective of individual nitrogen species concentration

Table 6. Maximum predicted nitrogen species concentration $(\mathrm{mg} / \mathrm{l})$ at different depth for extreme case input wastewater concentration for Kancheepuram soil from HYDRUS-1D model $\left(K_{\mathrm{d}}=3.4 \times 10^{-7}, K_{1}=\right.$ 0.45 per day, $K_{2}=0.04$ per day).

\begin{tabular}{lccccccrr}
\hline & \multicolumn{7}{c}{ Influent wastewater concentration (mg/l) } \\
\cline { 2 - 8 } & \multicolumn{7}{c}{$\mathrm{NH}_{4}-\mathrm{N}=50$} & \multicolumn{7}{c}{$\mathrm{NH}_{4}-\mathrm{N}=100$} & $\mathrm{NH}_{4}-\mathrm{N}=20$ & $\mathrm{NH}_{4}-\mathrm{N}=50$ \\
& $\mathrm{NO}_{3}-\mathrm{N}=20$ & $\mathrm{NO}_{3}-\mathrm{N}=50$ & $\mathrm{NO}_{3}-\mathrm{N}=50$ & $\mathrm{NO}_{3}-\mathrm{N}=100$ \\
\cline { 2 - 9 } Depth (cm) & $\mathrm{NH}_{4}-\mathrm{N}$ & $\mathrm{NO}_{3}-\mathrm{N}$ & $\mathrm{NH}_{4}-\mathrm{N}$ & $\mathrm{NO}_{3}-\mathrm{N}$ & $\mathrm{NH}_{4}-\mathrm{N}$ & $\mathrm{NO}_{3}-\mathrm{N}$ & $\mathrm{NH}_{4}-\mathrm{N}$ & $\mathrm{NO}_{3}-\mathrm{N}$ \\
\hline 50 & 1.42 & 48 & 2.82 & 103.0 & 0.57 & 47.0 & 1.42 & 101.0 \\
100 & 0.04 & 32.5 & 0.075 & 69.3 & 0.02 & 31.2 & 0.04 & 67.2 \\
150 & 0 & 21.3 & 0 & 45.5 & 0 & 20.5 & 0 & 44.1 \\
200 & 0 & 14.1 & 0 & 30.1 & 0 & 13.6 & 0 & 29.2 \\
250 & 0 & 9.31 & 0 & 19.9 & 0 & 8.94 & 0 & 19.2 \\
300 & 0 & 6.16 & 0 & 13.1 & 0 & 5.91 & 0 & 12.7 \\
350 & 0 & 4.09 & 0 & 8.73 & 0 & 3.92 & 0 & 8.44 \\
400 & 0 & 2.69 & 0 & 5.75 & 0 & 2.58 & 0 & 5.56 \\
\hline
\end{tabular}


Table 7. Maximum predicted nitrogen species concentration $(\mathrm{mg} / \mathrm{l})$ at different depth for extreme case input wastewater concentration for Ludhiana soil from HYDRUS-1D model $\left(\mathrm{K}_{\mathrm{d}}=3.4 \times 10^{-7}, \mathrm{~K}_{1}=0.45\right.$ per day, $\mathrm{K}_{2}=0.04$ per day).

\begin{tabular}{|c|c|c|c|c|c|c|c|c|}
\hline \multirow[b]{4}{*}{ Depth $(\mathrm{cm})$} & \multicolumn{8}{|c|}{ Influent wastewater concentration (mg/l) } \\
\hline & \multicolumn{2}{|c|}{$\begin{array}{l}\mathrm{NH}_{4}-\mathrm{N}=50 \\
\mathrm{NO}_{3}-\mathrm{N}=20\end{array}$} & \multicolumn{2}{|c|}{$\begin{array}{c}\mathrm{NH}_{4}-\mathrm{N}=100 \\
\mathrm{NO}_{3}-\mathrm{N}=50\end{array}$} & \multicolumn{2}{|c|}{$\begin{array}{l}\mathrm{NH}_{4}-\mathrm{N}=20 \\
\mathrm{NO}_{3}-\mathrm{N}=50\end{array}$} & \multicolumn{2}{|c|}{$\begin{array}{l}\mathrm{NH}_{4}-\mathrm{N}=50 \\
\mathrm{NO}_{3}-\mathrm{N}=100\end{array}$} \\
\hline & \multicolumn{8}{|c|}{ Effluent concentration (mg/l) } \\
\hline & $\mathrm{NH}_{4}-\mathrm{N}$ & $\mathrm{NO}_{3}-\mathrm{N}$ & $\mathrm{NH}_{4}-\mathrm{N}$ & $\mathrm{NO}_{3}-\mathrm{N}$ & $\mathrm{NH}_{4}-\mathrm{N}$ & $\mathrm{NO}_{3}-\mathrm{N}$ & $\mathrm{NH}_{4}-\mathrm{N}$ & $\mathrm{NO}_{3}-\mathrm{N}$ \\
\hline 200 & 4.15 & 53.5 & 8.29 & 115 & 1.66 & 53.7 & 4.15 & 115 \\
\hline 400 & 0.34 & 44.3 & 0.65 & 94.5 & 0.13 & 42.6 & 0.33 & 91.6 \\
\hline 600 & 0 & 34.2 & 0 & 73.0 & 0 & 32.8 & 0 & 70.6 \\
\hline 800 & 0 & 26.2 & 0 & 56 & 0 & 25.2 & 0 & 54.2 \\
\hline 1000 & 0 & 20.1 & 0 & 42.9 & 0 & 19.3 & 0 & 41.6 \\
\hline 1200 & 0 & 15.4 & 0 & 32.8 & 0 & 14.8 & 0 & 31.9 \\
\hline 1400 & 0 & 11.7 & 0 & 25.1 & 0 & 11.4 & 0 & 24.5 \\
\hline 1600 & 0 & 8.91 & 0 & 19.0 & 0 & 8.7 & 0 & 18.7 \\
\hline 1800 & 0 & 6.72 & 0 & 14.4 & 0 & 6.64 & 0 & 14.2 \\
\hline 2000 & 0 & 5.13 & 0 & 11.0 & 0 & 5.15 & 0 & 11 \\
\hline
\end{tabular}

variation. Similarly the concentration level of nitrate nitrogen was above the allowable limit nearly up to $350 \mathrm{~cm}$ for the total applied nitrogen concentration of $150 \mathrm{mg} / \mathrm{l}$. On the other hand, the predicted ammonium nitrogen concentration was very less for all depths in all application scenarios. This high concentration of nitrate nitrogen in all depths is due to the high nitrification rate which converts ammonium nitrogen to nitrate nitrogen and low denitrification rate.

The nitrogen dynamics at different depths for Ludhiana soil is shown in table 7 with similar nitrogen transformations assumed for Kancheepuram soil (table 6). The results show that the ammonium nitrogen concentration is relatively higher even at $200 \mathrm{~cm}$ depth $(0 \mathrm{mg} / \mathrm{l}$ for Kancheepuram soil and $4.15 \mathrm{mg} / \mathrm{l}$ for Ludhiana soil with $70 \mathrm{mg} / \mathrm{l}$ of total nitrogen application) in the case of Ludhiana soil as compared with the Kancheepuram soil, even though the partition coefficient was less for Ludhiana soil. It is observed that for Ludhiana soil, the groundwater is at risk for locations with water table greater than $1,000 \mathrm{~cm}$. This higher concentration of ammonium nitrogen in Ludhiana soil is mainly due to high hydraulic conductivity, whereas the ammonium nitrogen can convert to nitrate nitrogen in Kancheepuram soil due to low hydraulic conductivity (high residence time). Similarly, the nitrate nitrogen concentration was also observed to be very high for all depths in Ludhiana soil during all application scenarios. It is further observed from table 7 that the nitrate nitrogen concentration was above the allowable limit $(10 \mathrm{mg} / \mathrm{l})$ approximately up to $1,400 \mathrm{~cm}$ depth, when the total (ammonium-nitrogen and nitrate nitrogen) nitrogen applied was $70 \mathrm{mg} / \mathrm{l}$ and up to 2,000 $\mathrm{cm}$ depth, for $150 \mathrm{mg} / \mathrm{l}$ of applied total nitrogen. This shows that the applications of high nitrogen content wastewater for irrigation in Ludhiana soil will affect the groundwater quality even when the groundwater table is deep.

\section{Conclusions}

In this present study, soil column experiments were performed to investigate the dynamics of nitrogen species in water phase with different irrigation scenarios during the application of treated or partially treated wastewater. Furthermore, a numerical model is developed to simulate 
the transport of nitrogen species from wastewater experimented in a soil column. The onedimensional coupled water flow and nitrogen species transport model were solved using implicit finite difference scheme. To examine the performance of the developed model, the commercially available HYDRUS-1D software was also used to simulate the nitrogen species transport. From the experimental and model analysis, the following conclusions were arrived:

- The HYDRUS-1D and developed numerical model results were in good agreement with the experimentally observed nitrogen species concentration data.

- The computed van Genuchten parameters for Kancheepuram and Ludhiana soil using pressure plate apparatus and RETC software were appropriate to investigate the nitrogen species concentrations using HYDRUS-1D and developed models.

- A delayed appearance of the effluent at the bottom of the soil column was observed due to the low permeability of soil for paddy irrigation scenario in Kancheepuram soil $\left(6 \times 10^{-5}\right.$ $\mathrm{cm} / \mathrm{s})$ as compared with Ludhiana soil $\left(3.9 \times 10^{-4} \mathrm{~cm} / \mathrm{s}\right)$.

- The effluent was not collected for all intermittent wastewater application of groundnut irrigation in Kancheepuram soil and the effluent was collected during the intermittent wastewater application for wheat except during first wheat irrigation. The high concentration of nitrate nitrogen observed in the effluent for wheat irrigation scenario was due to the high background nitrate concentration in soil.

- Lesser value of linear partition coefficient of ammonium nitrogen $\left(3.4 \times 10^{-8} \mathrm{1} / \mathrm{mg}\right)$ increases the aqueous phase ammonium nitrogen $(22 \mathrm{mg} / \mathrm{l})$ and nitrate nitrogen $(40 \mathrm{mg} / \mathrm{l})$ concentration in Kancheepuram soil. On the other hand, higher value of partition coefficient $\left(3.4 \times 10^{-6} 1 / \mathrm{mg}\right)$ decreases the ammonium nitrogen $(2.5 \mathrm{mg} / \mathrm{l})$ and nitrate nitrogen $(8$ $\mathrm{mg} / \mathrm{l}$ ) concentration. However, the variation of linear partition coefficient in Ludhiana soil does not have much influence due to high background ammonium concentration in the soil.

- The ammonium nitrogen concentration decreases from $50 \mathrm{mg} / \mathrm{l}$ to $8 \mathrm{mg} / \mathrm{l}$ for the decrease in nitrification rate from $0.2 /$ day to $0.6 /$ day and the corresponding nitrate nitrogen was varying from $37 \mathrm{mg} / \mathrm{l}$ to $55 \mathrm{mg} / \mathrm{l}$ in Kancheepuram soil. Similarly, the ammonium nitrogen was varying between $2.5 \mathrm{mg} / \mathrm{l}$ and $5 \mathrm{mg} / \mathrm{l}$, and the nitrate nitrogen concentration varying between $8.5 \mathrm{mg} / \mathrm{l}$ and $10.5 \mathrm{mg} / \mathrm{l}$ for the nitrification rate between $0.25 /$ day and $0.65 /$ day in Ludhiana soil.

- The concentration of nitrate nitrogen is increasing from $25 \mathrm{mg} / \mathrm{l}$ to $100 \mathrm{mg} / \mathrm{l}$ in Kancheepuram soil and $9.5 \mathrm{mg} / \mathrm{l}$ to $10.25 \mathrm{mg} / \mathrm{l}$ in Ludhiana soil for the variation of denitrification rate from 0.5 /day to $0.1 /$ day and $0.06 /$ day to 0.02 /day respectively. However, denitrification rate does not have any impact on ammonium nitrogen concentration.

- Extreme case analysis shows that the application of high nitrogen content wastewater for irrigation in Ludhiana soil will affect the groundwater quality even when the groundwater table is deep due to high hydraulic conductivity as compared with Kancheepuram soil.

In over all, the developed numerical model and HYDRUS-1D software were predicting well with the observed ammonium and nitrate nitrogen concentration in the soil column experiments. The developed model can be further extended to study the influence of unsaturated soil hydraulic parameters and transformation rates on nitrogen species concentration in the context of groundwater contamination. 


\section{References}

Al-Lahham O, El-Assi N M and Fayyad M 2003 Impact of treated wastewater irrigation on quality attributes and contamination of tomato fruit. Agric. Water Manag. 61: 51-62

Antonopoulos V Z 1993 Simulation of water and nitrogen dynamics in soils during wastewater applications by using a finite-element model. Water Resources Manag. 7: 237-325

Antonopoulos V Z 2006 Water movement and heat transfer simulations in a soil under ryegrass. Biosyst. Eng. 95(1): 127-138

Asano T and Levine A D 1995 Wastewater reuse: A valuable link in water resources management. Water Qual. Int. 4: 20-24

Asano T and Levine A D 1996 Wastewater reclamation, recycling and reuse: Past, present, and future. Water Sci. Tech. 33: 1-14

Babiker I S, Mohamed M A A, Terao H, Kato K and Ohta K 2004 Assessment of groundwater contamination by nitrate leaching from intensive vegetable cultivation using geographical information system. Environ. Int. 29: 1009-1017

Balakrishnan M, Arul Antony S, Gunasekaran S and Natarajan R K 2008 Impact of dyeing industrial effluents on the groundwater quality in Kancheepuram (India). Indian J. Sci. Tech. 1(7): 1-8

Berlin M, Suresh Kumar G and Nambi I M 2013 Numerical modelling on fate and transport of nitrate in an unsaturated system under non-isothermal condition. Eur. J. Environ. Civil Eng. 17(5): 350-373

Berlin M, Suresh Kumar G and Nambi I M 2014a Numerical modelling on transport of nitrogen from wastewater and fertilizer applied on paddy fields. Ecol. Model. 278: 85-99

Berlin M, Suresh Kumar G and Nambi I M 2014b Numerical modeling on the effect of dissolved oxygen on nitrogen transformation and transport in unsaturated porous system. Environ. Model. Assess. 19(4): 283-299

Berlin M, Suresh Kumar G and Nambi I M 2014c Numerical modeling of biological clogging on transport of nitrate in an unsaturated porous media. Environ. Earth Sci. 73(7): 3285-3298

Bradford A, Brook R and Hunshal C S 2003 Wastewater irrigation in Hubli-Dharwad, India: Implications for health and livelihoods. Environ. Urban 15(2): 157-170

Brunetti G, Senesi N and Plaza C 2007 Effects of amendment with treated and untreated olive oil mill wastewaters on soil properties, soil humic substances and wheat yield. Geoderma 138: 144-152

CGWB 2007 Ministry of Water Resources, Government of India, North Western Region, Chandigarh, http://cgwb.gov.in/district_profile/punjab/ludhiana.pdf. Accessed 28 October 2014

Chen X, Wu H and Wo F 2007 Nitrate vertical transport in the main paddy soils of Tai Lake region, China. Geoderma 142: 136-141

Chinh L V, Hiramatsu L, Harada M and Mori M 2008 Nitrogen and phosphorus runoff modeling in a flat low-lying paddy cultivated area. Paddy Water Environ. 6: 405-414

Cho J Y 2003 Seasonal runoff estimation of N and P in a paddy field of central Korea. Nutr. Cycl. Agroecosyst. 65: 43-52

Cho J Y and Choi J K 2001 Nitrogen and phosphorus losses from a broad paddy field in central Korea. Commun. Soil Sci. Plan Anal. 32: 2395-2410

Cooper R L 1991 Public health concerns in wastewater reuse. Water Sci. Tech. 24: 55-65

Haijun S, Hailin Z, Jiasen W, Peikun J and Weiming S 2013 Laboratory Lysimeter analysis of $\mathrm{NH}_{3}$ and $\mathrm{N}_{2} \mathrm{O}$ emissions and leaching losses of nitrogen in a Rice-Wheat rotation system irrigated with nitrogen-rich wastewater. Soil Sci. 178(6): 316-323

Han K W, Cho J Y and Choi J K 1999 Annual runoff loading of nitrogen and phosphorus from a paddy field. Agric. Chem. Biotech. 42: 29-23

Iqbal M 2010 Nitrogen leaching from paddy field under different fertilization rates. Malaysian J. Soil Sci. 15: 101-114

Jang T, Jung M, Lee E, Park S, Lee J and Jeong H 2013 Assessing environmental impacts of reclaimed wastewater irrigation in paddy fields using bioindicator. Irrigation Sci. 31: 1225-1236

Jang T I, Kim H K, Seong C H, Lee E J and Park S W 2012 Assessing nutrient losses of reclaimed wastewater irrigation in paddy fields for sustainable agriculture. Agric. Water Manag. 104: 235-243 
Jang T I, Lee S B, Sung C H, Lee H P and Park S W 2010 Safe application of reclaimed water reuse for agriculture in Korea. Paddy Water Environ. 8: 227-233

Kaluarachchi J and Parker J C 1988 Finite element model of Nitrogen species transformation and transport in the unsaturated zone. J. Hydrol. 109: 249-274

Kang M S, Kim S M, Park S W, Lee J J and Yoo K H 2007 Assessment of reclaimed wastewater irrigation impacts on water quality, soil, and rice cultivation in paddy fields. J. Environ. Sci. Health A 42: 439-445

Kim J W, Kim J, Choi H and Schwartz F W 2004 Modeling the fate and transport of organic and nitrogen species in soil aquifer treatment process. Water Sci. Tech. 50(2): 255-261

Kim S M, Park S W, Lee J J, Benham B L and Kim H K 2007 Modeling and assessing the impact of reclaimed wastewater irrigation on the nutrient loads from an agricultural watershed containing rice paddy fields. J. Environ. Sci. Health A 42: 305-315

Kiziloglu F M, Turan M, Sahin U, Angin I, Anapali O and Okuroglu M 2007 Effects of wastewater irrigation on soil and cabbage-plant (Brassica olerecea var. Capitate cv. Yalova-1) chemical properties. J. Plant Nutr. Soil Sci. 170: 166-172

Lee M S, Lee K K, Hyun Y, Clement T P and Hamilton D 2006 Nitrogen transformation and transport modeling in groundwater aquifers. Ecol. Model. 192: 143-159

Liang X Q, Chen Y X, Li H, Tian G M, Ni W Z, He M M and Zhang Z J 2007 Modeling transport and fate of nitrogen from urea applied to a near-trench paddy field. Environ. Pollut. 150: 313-320

Lubello C, Gori R, Nicese F P and Ferrini F 2004 Municipal-treated wastewater reuse for plant nurseries irrigation. Water Res. 38: 2939-2947

MacQuarrie K T B, Sudicky E A and Robertson W D 2001 Multicomponent simulation of wastewaterderived nitrogen and carbon in shallow unconfined aquifers II. Model application to a field site. $J$. Contam. Hydrol. 47: 85-104

Mohammad N A 2007 Nitrate contamination of groundwater: A conceptual management framework. Environ. Impact Assess. Rev. 27: 220-242

Mojid M A, Biswas S K and Wyseure G C L 2012 Interaction effects of irrigation by municipal wastewater and inorganic fertilisers on wheat cultivation in Bangladesh. Field Crops Res. 134: 200-207

MSME 2014 Brief industrial profile of district Ludhiana, Micro, Small \& Medium Enterprise Development Institute, Govt. of India, Ministry of MSME, Industrial Area- B, Pratap Chowk, Ludhiana-141003. http:// dcmsme.gov.in/dips/Ludhiana.pdf. Accessed 28 October 2014

NATCOM 2004 India's initial national communication to the United Nations framework conversion on climate changes, National communication project, Ministry of environment and forests, Govt. of India. http://unfccc.int/resource/docs/natc/indnc1.pdf. Accessed 28 October 2014

Palese A M, Pasquale V, Celano G, Figliuolo G, Masi S and Xiloyannis C 2009 Irrigation of olive groves in Southern Italy with treated municipal wastewater: Effects on microbiological quality of soil and fruits. Agric. Ecosyst. Environ. 129: 43-51

Papadopoulos F, Parissopoulos G, Papadopoulos A, Zdragas A, Ntanos D, Prochaska C and Metaxa I 2009 Assessment of reclaimed municipal wastewater application on rice cultivation. Environ. Manag. 43: 135143

Pathak H, Joshi H C, Chaudhary A, Chaudhary R, Kalra N and Dwiwedi M K 1999 Soil amendment with distillery effluent for wheat and rice cultivation. Water Air Soil Pollut. 113: 133-140

Paul S A, Chavan S K and Khambe S D 2012 Studies on characterization of textile industrial waste water in Solapur city. Int. J. Chem. Sci. 10(2): 365-642

Pedrero F, Kalavrouziotis I, Alarcon J J, Koukoulakis P and Asano T 2010 Use of treated municipal wastewater in irrigated agriculture-Review of some practices in Spain and Greece. Agric. Water Manag. 97: $1233-1241$

Qiang L X, Lei X, Hua L, Miao H M, Chao Q Y, Jin L, Yu N E, Shi Y Y and Yingxu C 2011 Influence of $\mathrm{N}$ fertilization rates, rainfall, and temperature on nitrate leaching from a rainfed winter wheat field in Taihu watershed. Phys. Chem. Earth 36: 395-400

Ramana S, Biswas A K, Singh A B and Yadava R B R 2002 Relative efficacy of different distillery effluents on growth, nitrogen fixation and yield of groundnut. Bioresour. Tech. 81: 117-121 
Riley W J, Monasterio I O and Matson P A 2001 Nitrogen leaching and soil nitrate, nitrite, and ammonium levels under irrigated wheat in Northern Mexico. Nutr. Cycl. Agroecosys. 61: 223-236

Rinaldi M, Rana G and Introna M 2003 Olive-mill wastewater spreading in southern Italy: Effects on a durum wheat crop. Field Crops Res. 84: 319-326

Roose T and Fowler A C 2004 A mathematical model for water and nutrient uptake by plant root systems. $J$. Theor. Biol. 228: 173-184

Sheng Z 2005 An aquifer storage and recovery system with reclaimed wastewater to preserve native groundwater resources in El Paso, Texas. J. Environ. Manag. 75(4): 367-377

Tchobanoglous G and Burton F 1995 Wastewater engineering-treatment, disposal and reuse. Metcalf and Eddy, Inc. 3rd edition, McGraw-Hill, New York

Van Genuchten M, Leij F J Th and Yates S R 1991 The RETC code for quantifying the hydraulic functions of unsaturated soils. In: Version 1.0. EPA Report 600/2-91/065. U.S. Salinity Laboratory, USDA, ARS, Riverside, CA

Van Genuchten M Th 1980 A closed-form equation for predicting the hydraulic conductivity of unsaturated soils. Soil Sci. Soc. Am. J. 44: 892-898

Water Year 2007 District groundwater brochure, Kancheepuram district, CGWB, Ministry of Water Resources, Govt. of India, http://cgwb.gov.in/district_profile/tamilnadu/kancheepuram.pdf. Accessed 28 October 2014

Wu Q J, Ward A D, Workman S R and Salchow E M 1997 Applying stochastic simulation techniques to a deterministic vadose zone solute transport model. J. Hydrol. 197: 88-110

Yoon K S, Cho J Y, Choi J K and Son J G 2006 Water management and N, P losses from paddy fields in Southern Korea. J. Am. Water Resources Assoc. 42: 1205-1216

Zhao H, Zhang X, Xu S, Zhao X, Xie Z and Wang Q 2010 Effect of freezing on soil nitrogen mineralisation under different plant communities in a semi-arid area during a non-growing season. Appl. Soil Ecol. 45: $187-192$

Zhou M, Zhu B, Bahl K B, Zheng X, Wang T and Wang Y 2013 Nitrous oxide emissions and nitrate leaching from a rain-fed wheat-maize rotation in the Sichuan Basin, China. Plant Soil 362: 149-159

Zhu J G, Han Y, Liu G, Zhang Y L and Shao X H 2000 Nitrogen in percolation water in paddy fields with a rice/wheat rotation. Nutr. Cycl. Agroecosyst. 57: 75-82 